\title{
PREKOGRANIČNO ZAGAĐENJE OKOLIŠA IZMEĐU REPUBLIKE HRVATSKE I BOSNE I HERCEGOVINE: TRI STUDIJE SLUČAJA ${ }^{1}$
}

\author{
Tanja Jurić
}

Balokovićeva 9, 10000 Zagreb

e-mail: juric_tanja@yahoo.com

\begin{abstract}
Sažetak
Paralelno s razvojem suvremenog društva rastu i broj i vrste rizika s kojima se suvremeno društvo suočava. Jedan je vid takvih rizika prekogranično zagadenje okoliša. Napor država da se nose sa zagadenjem na svom teritoriju nedostatan je zbog činjenice da zagadenje nastaje i širi se svuda, ne ograničavajući se na državne granice. Iz tog razloga potrebna je suradnja medu državama kako bi se utvrdili standardi i mehanizmi za njegovo sprečavanje i smanjenje. U članku su predstavljene tri studije slučaja prekograničnog zagadenja okoliša izmedu Republike Hrvatske i Bosne i Hercegovine: zagadenje zraka u Slavonskom Brodu uzrokovano ispuštanjem štetnih tvari u zrak iz Rafinerije nafte Brod u BiH; poplave koje su pogodile regiju u svibnju 2014.; te takozvano "sedamnaesto jezero“" Plitvičkih jezera nastalo zbog neriješenog sustava odvodnje koje je uzrokovalo zagadenje izvora pitke vode u Bihaću u BiH. U sva tri slučaja opisani su specifični konteksti prekograničnog zagadenja, glavni akteri uključeni u problem i njegovo rješavanje, kao i načini na koje se države nose s prekograničnim zagadenjem. Pažnja je posvećena i zakonodavnim aktima Europske unije o zaštiti okoliša i svjetskim konvencijama na koje se oslanjaju zakonodavstva ovih dviju država. Analizom tri slućaja došli smo do zaključka da obje države trebaju unaprijediti svoju okolišnu politiku uz naglasak na važnost medudržavne suradnje kako bi se postiglo učinkovitije upravljanje rizikom prekograničnog zagađenja.
\end{abstract}

Ključne riječi: Bosna i Hercegovina, Hrvatska, poplave, prekogranično zagadenje okoliša, Rafinerija nafte Brod, „sedamnaesto jezero “ Plitvičkih jezera, upravljanje rizikom

\section{UVOD}

Prekogranično zagađenje okoliša predstavlja poseban vid ekološke problematike koji iziskuje potrebu za pronalaskom specifičnog načina njegovog rješavanja, zbog čega je kroz posljednjih nekoliko desetljeća donesen velik broj propisa na nacionalnoj, regionalnoj, europskoj i svjetskoj razini. Konkretni slučajevi prekograničnog zagađenja zahtijevaju

1 Članak je skraćena verzija diplomskog rada obranjenog u rujnu 2018. na Odsjeku za sociologiju Filozofskog fakulteta u Zagrebu pod mentorstvom doc. dr. sc. Tijane Trako Poljak 
razumijevanje specifičnih okolnosti država uključenih u problem, njihovih društvenih i političkih aktera i pravnih akata koji reguliraju njihovo rješavanje.

U radu su analizirana tri slučaja prekograničnog zagađenja između Republike Hrvatske i njenog regionalnog susjeda Bosne i Hercegovine, s kojim dijeli najdužu kopnenu granicu. Tri slučaja koja se analiziraju su: zagađenje zraka u Slavonskom Brodu uzrokovano radom Rafinerije nafte Brod u BiH, poplave koje su pogodile regiju u svibnju 2014. i za sobom ostavile neslućene posljedice te takozvano „sedamnaesto jezero" Plitvičkih jezera čije podzemne vode zbog neriješenog sustava odvodnje zagađuju pitku vodu u Bihaću u BiH.

Cilj je rada kroz analizu političkih, ekonomskih, ekoloških i socijalnih aspekata ukazati na socijalno-ekološke rizike zagađenja koje ne poznaje državne granice i koje zahtijeva sporazumno rješavanje između dviju država. Iako su obje države potpisnice mnogih međunarodnih akata o zaštiti okoliša, sporna je njihova primjena. Hrvatska je kao članica Europske unije preuzela mnoge direktive $\mathrm{EU}$ o zaštiti okoliša dok $\mathrm{BiH}$ još uvijek nije ispunila uvjete za ulazak u EU što dodatno usložnjava uspješnu implementaciju europskih propisa. Različit stupanj gospodarske razvijenosti među državama također utječe na način ophođenja prema okolišnim problemima. Neka od važnih pitanja koja se postavljaju u radu su: koje su ekološke i socijalne posljedice prekograničnog zagađenja za obje države, koji su akteri uključeni u rješavanje problema, koji se aspekti upravljanja rizicima mogu primijeniti na ovakvu vrstu problema s obzirom na literaturu iz sociologije rizika, jesu li države prenijele međunarodne propise o zaštiti okoliša na svoja zakonodavstva te koje vrijednosti imaju prevagu kod ovakvih pitanja, očuvanje okoliša i ljudskih života ili ekonomska dobit?

\section{PREKOGRANIČNO ZAGAĐENJE OKOLIŠA}

Kako bismo shvatili pojam prekograničnog zagađenja okoliša potrebno je definirati zagađenje okoliša. Zagađenje okoliša je „unošenje kemijskih supstancija ili emisija stranih tvari u okoliš (ili njegove sastavnice: vodu, zrak, tlo, more, atmosferu) koje štetnim djelovanjem potiču rizik od propadanja, ugrožavaju zdravlje čovjeka i drugih bića te izazivaju kvalitativne promjene u okolišu za razliku od onečišćenja (engl. contamination)“ (Cifrić, 2012:398). Onečišćenje je definirano kao „mjerljiv stupanj promjene kvalitete okoliša (ili njegovih sastavnica: zrak, voda, more, tlo, klima) koji ne ugrožava samoobnovljivost (komponenata) ekosustava" (Cifrić, 2012:275). S druge strane, ukoliko dođe do prekoračenja maksimalne dopuštene koncentracije (MDK) štetnih tvari u okolišu dolazi do zagađenja (Cifrić, 2012:398). Slične definicije pojmova nudi Kaštelan-Macan referirajući se na nekoliko rječnika hrvatskog jezika. Prema Rječniku hrvatskog jezika Vladimira Anića onečistiti znači „učiniti nečistim; učiniti da više ne bude čisto“, a zagadivati znači ,širenjem bakterija, virusa, smradova i štetnih tvari u tlu, zraku i vodi kvariti kvalitetu života i odnose između prirode i čovjeka kao njezina dijela“ (Anić, 1991, prema Kaštelan-Macan, 2010:547). Također navodi definicije iz Rječnika hrvatskog jezika Leksikografskog zavoda „Miroslav Krleža“ u kojem je zagadivač definiran kao „čovjek koji zagađuje okoliš; industrijski pogon i njegov proizvod koji izbacuje nečiste, štetne 
tvari; zagađivalo“, a onečisćivač kao „tvar koja uzrokuje onečišćenje; osoba ili djelatnost koja onečišćuje okoliš““ (Šonje, 2000, prema Kaštelan-Macan, 2010:547).

Nastavno na definiciju zagađenja, prekogranična zagađenja ili prekogranični utjecaji „odnose se na sva zagađenja koja dolaze zrakom ili vodom iz neke druge države, a utječu na okoliš “" (Cifrić, 2012:303). Prema Thomasu Merrillu, prekogranično je zagađenje događaj u kojem se potencijalno opasna tvar, nastala unutar teritorija jedne političke nadležnosti (države izvora / zagađivača), prenosi fizički putem prirodnih medija kao što su zrak, voda ili tlo na teritorij druge političke nadležnosti (ugrožene / zagađene države) (Merrill, 1997:968).

Neki od pojmova koji se vežu uz prekogranično zagađenje i koriste se u pravnim normama su pravo na zagadivanje (engl. right on pollution) koje Cifrić opisuje kao negativno definiran pojam prava na čist okoliš u okviru kojeg država zagađivač priznaje da zagađenje postoji, ali je u skladu s propisanim zakonskim granicama ili prema postojećem emisijskom certifikatu (Cifrić, 2012:302). Još jedno važno načelo za prekogranično zagađenje je zagadivač plaća (engl. polluter pays) prema kojem je „svaki zagađivač dužan snositi troškove zagađivanja, tj. troškove uklanjanja posljedica zagađivanja okoliša “ (Cifrić, 2012:399). Prema Cifriću, ovo načelo može se provesti putem određivanja poreza državi zagađivaču, odnosno ekoporeza ili na način da država zagađivač otkupi pravo na zagađivanje, odnosno pribavi emisijski certifikat (Cifrić, 2012:399). Država pomoću emisijskog certifikata može otkupiti pravo na zagađenje od nerazvijenih država i preuzeti njihovu kvotu zagađenja što autor smatra spornim jer ne dolazi do sveukupnog smanjenja zagađenja (Cifrić, 2012:123). Ova i druga pravila navode se u zakonodavstvima o zaštiti okoliša pojedinačnih država, ali i onima koji se tiču djelovanja šire međunarodne zajednice, primjerice Europske unije.

\section{PROPISI EUROPSKE UNIJE I SVJETSKE KONVENCIJE O OKOLIŠU; SPORAZUMI IZMEĐU HRVATSKE I BOSNE I HERCEGOVINE}

Režim Europske unije uspostavljen u cilju regulacije okolišnih pitanja važan je pri analiziranju okolišne politike njenih članica i zemalja koje su u pretpristupnim pregovorima. Od direktiva EU koje se tiču zagađenja zraka i neizostavne su za studiju slučaja o zagađenju zraka u Slavonskom Brodu ističemo „Direktivu 2001/81/EZ Europskog parlamenta i Vijeća od 23. listopada 2001. o nacionalnim gornjim granicama emisije za određene onečišćcujuće tvari“ (NEC Direktiva) (Sl. list EU, 309/22) koju je RH prenijela u svoje zakonodavstvo „Uredbom o emisijskim kvotama za određene onečišćujuće tvari u zraku u Republici Hrvatskoj“ (NN 108/2013, 19/2017; Zelena akcija, 2009:14) dok podatke o provođenju direktive u $\mathrm{BiH}$ nismo uspjeli pronaći. Druga važna direktiva je „Direktiva 2010/75/EU Europskog parlamenta i Vijeća od 24. studenoga 2010. o industrijskim emisijama (integrirano sprečavanje i kontrola onečišćenja)“ (Sl. list EU, 334/17) prenesena u Zakon o zaštiti okoliša RH (NN 80/13, 153/13, 78/15, 12/18, 118/18), a u BiH se 
trebala početi primjenjivati za nova postrojenja od 2018. godine (Jovičić, 2017). „Direktiva 2001/42/EZ Europskog parlamenta i Vijeća od 27. lipnja 2001. o procjeni učinaka određenih planova i programa na okoliš (SEA Direktiva) (Sl. list EU, 197/30) prenesena je na Zakon o zaštiti okoliša RH (NN 80/13, 153/13, 78/15, 12/18, 118/18), a u BiH su sporni podzakonski akti za njeno provođenje (Granić i sur., 2008:17).

Od međunarodnih ugovora koji se odnose na zaštitu okoliša ističemo „Konvenciju o procjeni utjecaja na okoliš preko državnih granica" (Espoo, 1991) čije su stranke BiH (Sl. glasnik BiH-MU 08/09) i Hrvatska (NN-MU 6/96) te se na ovu konvenciju aktivisti za čist zrak u Slavonskom Brodu često pozivaju. Važna konvencija o zaštiti zraka je i „Konvencija o prekograničnom onečišćenju zraka na velikim udaljenostima" (CLRTAP) (Ženeva, 1979) te su obje države stranke Konvencije (Sl. list RBiH 13/94; NN-MU 12/93), ali je njeno provođenje u $\mathrm{BiH}$ sporno jer nije potpisala većinu protokola uz konvenciju (Granić i sur., 2008:7). BiH i Hrvatska su stranke „Konvencije o prekograničnim učincima industrijskih nesreća“" (Helsinki, 1992) (Sl. glasnik BiH-MU 16/12; NN-MU 7/1999) te „Konvencije o pristupu informacijama, sudjelovanju javnosti u odlučivanju i pristupu pravosuđu u pitanjima okoliša" (Aarhus, 1998) (Sl. glasnik BiH-MU 08/08; NN-MU 1/07) i bitna je jer uključuje javnost u rasprave o okolišnim problemima.

U pogledu zaštite voda i regulacije vodne politike najvažnija je „Direktiva 2000/60/EZ Europskog parlamenta i Vijeća od 23. listopada 2000. o uspostavi okvira za djelovanje Zajednice u području vodne politike“ (Sl. list EU, 327/1) ili „Okvirna direktiva EU o vodama“ čija je svrha uspostavljanje okvira za zaštitu svih voda, sprečavanje daljnjeg uništavanja i ponovno uspostavljanje dobrog statusa vodnih i kopnenih sustava i močvara koje izravno ovise o vodi (Zelena akcija, 2009:9). Prema ovoj direktivi rađeni su zakoni o vodama u RH i BiH. „Direktiva 2007/60/EZ Europskog parlamenta i Vijeća od 23. listopada 2007. o procjeni i upravljanju rizicima od poplava" (Sl. list EU, 288/27) prenesena je u Zakon o vodama Republike Srpske (Sl. glasnik RS 50/06, 92/09) (UNDP Bosna i Hercegovina, 2017) te su neke od odrednica Direktive prenesene $u$ „Uredbu o vrstama i sadržaju planova zaštite od štetnog djelovanja voda" (Sl. novine FBiH 26/09) (Institut za hidrotehniku Građevinskog fakulteta u Sarajevu, 2013:1). U Republici Hrvatskoj direktiva je prenesena u Zakon o vodama (NN 153/09, 63/11, 130/11, 56/13, 14/14, 46/18). Od međunarodnih ugovora koji se tiču zaštite voda potrebno je spomenuti „Konvenciju o suradnji na zaštiti i održivoj uporabi rijeke Dunav" (Sofija, 1994) čije su stranke između ostalih BiH (Sl. glasnik BiH 65/05) i RH (NN-MU 02/1996) te su obje države članice Međunarodne komisije za zaštitu rijeke Dunav (ICPDR). Obje su države stranke „Konvencije o zaštiti i uporabi prekograničnih vodotoka i međunarodnih jezera“ (Helsinki, 1992) (Sl. glasnik BiH 8/09; NN-MU 4/1996). „Okvirni sporazum o slivu rijeke Save" (FASRB) (Kranjska Gora, 2002) potpisale su Srbija, Slovenija, Hrvatska (NN-MU 14/2003) i BiH (Sl. glasnik BiH 8/2003), a za provođenje sporazuma zadužena je Savska komisija ili Međunarodna komisija za sliv rijeke Save (Komatina i Zlatić-Jugović, 2010:250). Ove četiri države 2015. potpisale su „Deklaraciju mreže Sava Parks" s ciljem prekogranične zaštite rijeke Save i njenih poplavnih površina i očuvanja bioraznolikosti (Ministarstvo turizma RH, 2015). 
Što se tiče svjetskih konvencija o zaštiti prirode obje su države stranke „Konvencije o zaštiti svjetske kulturne i prirodne baštine“ (Pariz, 1972) (Sl. list RBiH 25/93; NN-MU 12/93), „Konvencije o biološkoj raznolikosti“ (Rio de Janeiro, 1992) (Sl. glasnik BiHMU 12/02; NN-MU 6/96) te „Konvencije o zaštiti europskih divljih vrsta i prirodnih staništa" (Bern, 1979) (Sl. glasnik BiH-MU 08/08; NN-MU 6/00). U pogledu ekološke mreže Natura 2000 Europske unije koja se odnosi na zaštitu prirode u Europi, FBiH donijela je „Uredbu o programu Natura 2000 - zaštićena područja u Evropi“ (Sl. novine FBiH, 41/11) dok je Hrvatska donijela „Uredbu o ekološkoj mreži“ (NN $124 / 2013,105 / 2015$ ), ali je potrebno detaljnije ispitati provođenje njenih smjernica. Adekvatna zaštita prirode moguća je tek uz prekograničnu suradnju među državama. Jedan od primjera suradnje je projekt „Velika pobjeda za Dinarski luk“ kojim se povezuje parkove dinarske regije u cilju očuvanja (A. H., 2013) te bi se slični projekti trebali dodatno razvijati.

Od bilateralnih sporazuma između RH i BiH o zaštiti okoliša ističemo „Sporazum između Vlade Republike Hrvatske i Vijeća ministara Bosne i Hercegovine o suradnji u području zaštite okoliša i održivog razvoja" (Sl. glasnik BiH-MU 2/17; NN-MU 4/2016). Sporazum je bitan jer propisuje suradnju u zaštiti okoliša, razmjenu iskustava u usklađivanju zakonodavstva s pravnom stečevinom Europske unije, razmjenu znanja, pripremu i realizaciju zajedničkih projekata itd. (NN-MU 4/2016 čl.3). Jedan od ranijih ugovora između država koji se odnosi na uređenje vodnogospodarskih odnosa je „Ugovor između Vlade Republike Hrvatske i Vlade Bosne i Hercegovine o uređenju vodnogospodarskih odnosa" (NN-MU 12/96; Sl. glasnik BiH-MU 6/96). U listopadu 2017. između ministra zaštite okoliša i energetike RH i ministra industrije, energetike i rudarstva RS-a potpisan je Protokol o suradnji na realizaciji projekta kojim se omogućuje plinofikacija Rafinerije nafte Brod (Vlada RH, 2017) za koju se smatra kako će povoljno utjecati na smanjenje zagađenja zraka u Slavonskom Brodu.

\section{METODOLOGIJA: TRI STUDIJE SLUČAJA PREKOGRANIČNOG ZAGAĐENJA}

\subsection{Zagadenje zraka u Slavonskom Brodu}

\subsubsection{Opis slučaja}

Zagađenje zraka koje ima nepovoljan utjecaj na okoliš, kvalitetu života i zdravlje ljudi predstavlja dugoročan problem s kojim se suočavaju građani Slavonskog Broda. Uzrok zagađenja najčešće se traži preko granice Republike Hrvatske, u Rafineriji nafte Brod koja je smještena u Brodu u entitetu Republike Srpske, u BiH. Rafinerija 2007. dolazi u vlasništvo ruske kompanije Zerubežnjeft koja je obnavlja i stavlja u pogon 2008. što se navodi kao početak zagađenja zraka u Slavonskom Brodu (Nadilo, 2014:270).

Prerada ruske nafte $s$ visokim udjelom sumpora, između 2 i 2,5\%, za razliku od arapske ili hrvatske nafte s nižim udjelom sumpora, oko 1\% (Nadilo, 2014:272), dovodi do 
ispuštanja štetnih tvari u zrak predstavljajući velik rizik za okoliš i ljude. Prema istraživanju Gvozdić i suradnika o zagađenosti zraka u Slavonskom Brodu, povišena koncentracija $\mathrm{H}_{2} \mathrm{~S}$ i $\mathrm{SO}_{2}$ dovodi se u vezu s jugozapadnim vjetrom i ukazuje na rafineriju u Brodu kao njihovom izvoru (Gvozdić i sur., 2011:1140). Kauzalnost između Rafinerije i zagađenja zraka u Slavonskom Brodu pokazalo je i istraživanje Instituta za medicinska istraživanja iz 2014. koje upućuje na to da je glavni uzročnik zagađenja sumporovodikom $\left(\mathrm{H}_{2} \mathrm{~S}\right)$ upravo Rafinerija (Ministarstvo zaštite okoliša i energetike, 2014). Trend zagađivanja zraka u Slavonskom Brodu nastavlja se i danas što se može pratiti na web-stranici Hrvatske agencije za okoliš i prirodu (2018) koja ažurira podatke satnih mjerenja zagađenosti zraka na mjernim postajama.

Iako katastar zagađivača u Slavonskom Brodu ne postoji, prema „Izvješću o stanju kvalitete zraka na području Brodsko-posavske županije u 2014. godini“ Upravnog odjela za komunalno gospodarstvo i zaštitu okoliša Brodsko-posavske županije, u gradu Slavonskom Brodu postoji pet dominantnih izvora zagađenja: 1. izvor sumpora nastao korištenjem teškog loživog ulja i ugljena kao energenta uz pretpostavku da su glavni uzročnici Rafinerija Brod i Kotlovnica Slavonija 1, 2. proizvodnja naftnih derivata, sagorijevanje otpadnog ulja i neprerađenih naftnih derivata uz nastanak velikih količina ozona što se također pripisuje Rafineriji, 3. izgaranje drva i biomase u kućnim ložištima i poljoprivredi, 4. promet te 5 . onečišćenje metalima što ukazuje na metaloprerađivačku industriju grupacije Đuro Đaković (Upravni odjel za komunalno gospodarstvo i zaštitu okoliša Brodsko-posavske županije, 2015:16-17). Zagađenje zraka u Slavonskom Brodu ne može se isključivo pripisati rafineriji u $\mathrm{BiH}$ te je potreban integrirani pristup zagađenju koji podjednako uključuje lokalne i prekogranične zagađivače.

\subsubsection{Glavni akteri uključeni u problem zagadenja zraka u Slavonskom Brodu}

Prije nego je zagađenje zraka postalo aktualan problem aktivnim radom Rafinerije, javila su se previranja između dva entiteta $\mathrm{BiH}$ o privatizaciji naftnog sektora Republike Srpske pa samim tim i Rafinerije. Premještanje kontrole i distribucije goriva isključivo u entitet Republike Srpske značilo je monopol nad naftnom industrijom i ugrožavanje regionalnih distributera poput INA-e, MOL-a i OMV-a (Knezović, 2006). Na problematičnost provođenja privatizacije apelirao je i Transparency International u $\mathrm{BiH}$ prema kojem je privatizacija izvršena netransparentno i nezakonito uz mogućnost da su novi vlasnici Rafinerije domaći kupci umjesto ruske kompanije (Knezović, 2007).

Zagađenje zraka u Slavonskom Brodu predstavnici vlasti Republike Srpske često negiraju pa tako predsjednik RS-a Milorad Dodik izjavljuje da „Rafinerija u Bosanskom Brodu radi po ekološkim dozvolama koje je dobila od vlasti Republike Srpske i po tome nadilazi standarde koji su prisutni u samoj Hrvatskoj" (Dodik, 2013, prema S. V., 2013). Hrvatska se strana ne slaže jer se na teritoriju BiH ne primjenjuju ekološki standardi Europske unije („Alarmantno onečišćenje u Slavonskom Brodu“, 2016). Predstavnici grupe Optima, upravljačke kompanije Zerubežnjefta, zauzimaju sličan stav vlastima RS-a, iako se u kasnijim priopćenjima navodi kako se radi na rekonstrukciji Rafinerije i smanjenju zagađenja te da se planira provođenje plinofikacije (Ministarstvo zaštite okoliša i energetike, 2016). 
Što se tiče suradnje između dviju država potrebno je istaknuti osnivanje Radne skupine za prekograničnu suradnju o problemu zagađenja između Brodsko-posavske županije i općine Brod 2009. (I. M., 2009) te osnivanje Povjerenstva za praćenje poboljšanja kvalitete zraka na području Slavonskog Broda 2014. (Galović, 2014). Također, 2016. potpisan je "Sporazum o suradnji u području zaštite okoliša i održivog razvoja“ (NNMU 4/2016; Sl. glasnik BiH-MU 2/17) između Vijeća ministara BiH i Vlade RH te je kao jedan od najvažnijih problema istaknuto prekogranično zagađenje uzrokovano radom Rafinerije (Tot-Đerđ, 2016).

U pogledu djelovanja civilnog društva u Hrvatskoj, građani Slavonskog Broda svoje nezadovoljstvo najčešće izražavaju kroz održavanje prosvjeda i apelima prema Vladi RH. U otvorenom pismu Vladi naveli su: „Brodani više ne mogu trpjeti. Pet godina čekanja bez ikakvog rezultata djeluje zaista sumorno. Brođani kao i svi stanovnici Brodsko-posavske županije imaju ustavno pravo na čist $i$ zdrav zrak, to jest na zdravlje $i$ život! Nadamo se da za rješenje nećemo morati potražiti pomoć izvan granica RH." (Tot-Đerđ, 2014). Predsjednik Eko kvarnera Vjeran Piršić istaknuo je kako je Vlada RH mogla iskoristiti međunarodne mehanizme protiv zagađenja kao što su Konvencija Espoo i Konvencija LRTAP dok su iz Zelene akcije istaknuli da je jedan od mehanizama djelovanja podizanje tužbe Europskom sudu za ljudska prava (Kelava, 2011). Još jedan od pokušaja zaustavljanja zagađenja bio je prijedlog stopiranja dotoka nafte Rafineriji hrvatskim nafotovodom JANAF-om uz prijetnje tužbom („Brođani pripremaju ekološku tužbu“, 2017). Od djelovanja hrvatskih institucija prema institucijama Europske unije o zagađenju zraka u Slavonskom Brodu ističemo iznošenje amandmana hrvatske zastupnice u Europskom parlamentu Marijane Petir čime je ovaj problem unesen u „Izvješće o napretku BiH“ u 2015. (Balen, 2015).

Kasniji događaji tiču se plinofikacije Rafinerije o kojoj su također postojala previranja između Vlade RS i Vlade RH, ali je ipak u listopadu 2017. između ministara RS-a i RH potpisan Protokol o suradnji na realizaciji projekta kojim se omogućuje plinofikacija (Vlada RH, 2017). Potpisivanje Protokola ponovno dovodi do razmirica između entiteta u BiH pa tako Almir Bečarević iz kompanije BH Gas tvrdi kako u pregovorima nije uzet $\mathrm{u}$ obzir interes cijele $\mathrm{BiH}$ čime je ugrožen projekt izgradnje plinovoda Brod-Zenica koji bi omogućio snabdijevanje plinom šire područje države umjesto pogodovanja isključivo Rafineriji (Maglajlija, 2017). Na potpisivanje protokola reagirao je i predsjedavajući Vijeća ministara BiH Denis Zvizdić tvrdeći kako je Hrvatska narušila međunarodno-pravni subjektivitet $\mathrm{BiH}$ potpisivanjem protokola s entitetom Republike Srpske za koji nije postojala suglasnost Parlamenta BiH na državnom nivou (Ćumurović, 2017).

Za provođenje plinofikacije zadužene su hrvatske tvrtke Plinacro i Crodux koje se s ruskim vlasnikom Zerubežnjeftom razilaze u interesima oko realizacije projekta i cijeli je proces odužen pa je predsjednica RH Grabar-Kitarović intenzivirala dogovore („Hrvatska: Plinofikacija rafinerije“, 2018). Osim navedenog, situacija oko plinofikacije dodatno se zakomplicirala ekološkim incidentom kada je tvrtka Crodux provodila ispitivanje postojećeg produktovoda od Slobodnice do rafinerije u Brodu u ožujku 2018. pri čemu je došlo do njegovog puknuća i izlijevanja ugljikovodika u tlo što je prouzročilo zagađenje pitke vode u Slavonskom Brodu. Unatoč zagađenju Crodux ne priznaje odgo- 
vornost za nastalu štetu (N. D., 2018). Još jedan incident dogodio se u samoj Rafineriji u listopadu 2018. kad je došlo do eksplozije i požara pri čemu je smrtno stradao jedan radnik. Prema službenim izvješćima, nije došlo do prekoračenja štetnih tvari u zrak, ali je zagađen dio rijeke Save naftnom mrljom te je izvršena sanacija („Na Savi se pojavila velika naftna mrlja“, 2018). S obzirom na zastarjelu tehnologiju koju Rafinerija koristi ovakav incident ne iznenađuje te se često govori o potrebi za modernizacijom Rafinerije. Generalni direktor Zerubežnjefta, Sergej Kudrjašov u dogovorima je oko plinofikacije, između ostalog, istaknuo kako je kompanija investirala 6 milijuna dolara u modernizaciju pogona (,Što prije građanima Sl. Broda moramo osigurati čisti zrak“, 2018). U svom osvrtu na problem zagađenja, bivši predsjednike INA-e Davor Štern dodao je kako plinofikacija ne bi riješila cjelokupan problem zagađenja zbog vrste nafte s visokim udjelom sumpora koju Rafinerija prerađuje (Lacić i Mikulić, 2018).

\subsubsection{Zakonski akti o zaštiti okoliša u BiH i RH}

U Bosni i Hercegovini zakoni o zaštiti okoliša doneseni su na nivou entiteta, u Republici Srpskoj na snazi je Zakon o zaštiti životne sredine (Sl. glasnik RS 71/2012, 79/2015), u FBiH Zakon o zaštiti okoliša (Sl. novine FBiH 33/03, 38/09). U pregledu stanja okoliša u BiH Ekonomske komisije UN-a za Europu iz 2011. istaknuto je da „nepostojanje državnog zakona o okolišu kontinuirano pogoršava čitav niz problema, kao što je razuđenost nadležnosti za zakone u sektoru okoliša i upravljanje okolišem na svim upravnim nivoima" (Ekonomska komisija Ujedinjenih naroda za Europu, 2011:3). Vijeće ministara BiH 2017. usvaja Strategiju zaštite okoliša kojom je planirano usklađivanje zakona o okolišu između entiteta BiH i Brčko Distrikta sa zakonima EU (J. K., 2017). BiH također nema Strategiju održivog razvoja, ali je planirano njeno donošenje („BiH nema strategiju održivog razvoja“, 2017). U Republici Srpskoj za okoliš je zaduženo Ministarstvo za prostorno uređenje, građevinarstvo i ekologiju, u FBiH Federalno ministarstvo okoliša i turizma, uz deset ministarstava za svaki kanton dok je u Brčko Distriktu za okoliš zadužena Skupština (Granić i sur., 2008:21). Složena struktura upravljačke vlasti ide u prilog tvrdnji Ekonomske komisije. Na državnoj razini djeluju Odjel za zaštitu okoline Ministarstva vanjske trgovine i ekonomskih odnosa te Koordinacijski komitet za okoliš i oba tijela zadužena su za pregovore i usklađivanje zakona o okolišu te se bave prekograničnom suradnjom (Granić i sur., 2008:21). U BiH također ne postoji agencija za zaštitu okoliša (Terzić, 2013) dok u Hrvatskoj djeluje Hrvatska agencija za zaštitu okoliša i prirodu. U Hrvatskoj je za okoliš zaduženo Ministarstvo zaštite okoliša i energetike, na snazi su Zakon o zaštiti okoliša (NN 80/13, 153/13, 78/15, 12/18, 118/18) i Strategija održivog razvitka (NN 30/2009).

\subsubsection{Diskusija}

Rizik od zagađenja s kojim se suočavaju građani Slavonskog Broda, ali i Broda u BiH se u okvirima sociologije rizika može svrstati pod kategoriju proizvedenih ekoloških rizika. Proizvedeni rizici djelo su čovjeka, ne odnose se na prirodne katastrofe, suše, potrese i slično već su posljedica ljudske intervencije u prirodi (Giddens, 2007:65). Također se 
može svrstati pod tehnološke rizike koji nastaju upotrebom različitih tipova tehnologije (Čaldrović, 1995:12) i proizvod su ljudske djelatnosti, a javnost ih često ne razumije (Čaldarović, 1995:23-24).

U Rafineriji nafte Brod zaposlen je veliki broj ljudi, a svjesno preuzimanje rizika od zagađenja radi ekonomske dobiti pogoduje vlasnicima Rafinerije, vlastima Republike Srpske, ali i zaposlenicima čija egzistencija ovisi o njenom radu. Prema Neilu Carteru, zemlje u razvoju koje nemaju dobre socijalne i ekonomske uvjete rijetko se bave ekološkim problemima i posljedicama svojih aktivnosti (Carter, 2004:271) što se može primijeniti i na Brod u $\mathrm{BiH}$ jer se radi o državi koja nema visok stupanj ekonomske razvijenosti. Istovremeno, radom Rafinerije ugrožena je priroda i kvaliteta života ljudi preko granice kojima je rizik od zagađenja nametnut. Kako Čaldarović ističe, javnost lakše prihvaća rizike koji nisu nametnuti, podjednako su raspoređeni i za koje nema alternative (Čaldarović, 1995:109).

Iako u Slavonskom Brodu postoje i drugi izvori zagađenja, rafinerija u Brodu je naročito sporna jer ju kao izvor zagađenja građani Slavonskog Broda nisu svojevoljno odabrali, ali i zbog razmjera zagađenja. Također, činjenica da nafta stiže u Rafineriju hrvatskim naftovodom JANAF-om doveo je u sukob javni i civilni sektor u Republici Hrvatskoj. U okvirima sociologije rizika možemo reći da je u ovom slučaju izostala „klima povjerenja" i dobra komunikacija vlasti i stručnjaka prema javnosti što onemogućuje učinkovito upravljanje rizikom (Čaldarović, 1995:104). Javnosti se pružaju različite informacije o modernizaciji pogona, rokovima za smanjenje zagađenja i sl. dok bi boljoj komunikaciji institucija s građanima mogao doprinijeti najavljeni projekt „Edukacija i obavješćivanje građana o kvaliteti zraka u Slavonskom Brodu“ Grada Slavonskog Broda i Brodsko-posavske županije (Vlada RH, 2018).

U pogledu ekoloških standarda naročito je problematično njihovo primjenjivanje u $\mathrm{BiH}$. Jedan od primjera je primjena standarda IPPC o integriranom sprečavanju i kontroli zagađenja u ekološkoj dozvoli za Rafineriju iz 2016. godine na koje se $\mathrm{BiH}$ očitovala kako ih nema obvezu sprovoditi (Ministarstvo zaštite okoliša i energetike RH, 2016). Prema Hurrellu, „najslabija veza u lancu međunarodne suradnje u zaštiti okoliša možda ne leži u teškoćama oko dogovora formalnih sporazuma nego prije u osiguranju da se ti sporazumi učinkovito provode" (Hurrell, 1995, prema Carter, 2004:267). Osim zagađenja koje uzrokuje Rafinerija, u Slavonskom Brodu potrebno je riješiti pitanje lokalnih zagađivača.

\subsection{Poplave na području Hrvatske i BiH u svibnju 2014. godine}

\subsubsection{Opis slučaja}

Sredinom svibnja 2014. iznad Jadranskog mora formiralo se polje niskog zračnog tlaka koje je sa suptropskim zrakom razvilo jaku ciklonu uzrokujući velike količine kiše koja se najduže zadržala iznad Balkana (RIMETEO, 2014). Nivo rijeke Save koja čini granicu između Hrvatske i $\mathrm{BiH}$ te $\mathrm{BiH}$ i Srbije narastao je do neslućenih razmjera kada su se Sava i mnoge od njenih pritoka izlile iz svojih korita i sve tri države pogodile poplavama. 
U BiH najviše pogođeni gradovi su Maglaj, Doboj, Tuzla, Derventa, Brčko, Prijedor, Bijeljina, Čelinac, Janja, Travnik, Živinice, Zenica, Zavidovići, Vareš, Ključ, Banja Luka (RIMETEO, 2014). U Srbiji stradali su gradovi Obrenovac, Sremska Mitrovica, Paraćin, Krupanj, Šabac, Svilajnac, Petrovac na Mlavi, Smederevska Palanka, a u Hrvatskoj istočni dio zemlje; sela Račinovci, Rajevo Selo, Gunja, Vrbanja, Soljani, Bošnjaci, Drenovci, Strošinci, Đurići, Posavski Podgajci (RIMETEO, 2014). U BiH evakuirano je 950 tisuća ljudi, a broj ugroženih iznosio je milijun i pol („,BiH: 1,5 milijuna ljudi pogođeno poplavama“, 2014). U Hrvatskoj evakuirano je preko 17 tisuća ljudi (Ministarstvo vanjskih i europskih poslova RH, 2014), u Srbiji preko 30 tisuća („Vladin Izveštaj o poplavama“",2014). Za vrijeme poplava osnovani su privremeni prihvatni centri za evakuirano stanovništvo, poplavljeni su mnogi stambeni i poslovni objekti, javne ustanove, stradale su poljoprivredne površine, a evakuiran je i dio stoke.

Poplave koje su zadesile regiju opisane su kao rijedak fenomen koji nije zabilježen otkako postoje hidrometeorološka promatranja na ovim područjima u zadnjih 120 godina. U tri dana pala je količina kiše koja u prosjeku padne u tri mjeseca (Međunarodna komisija za sliv rijeke Save, 2014). Institut za istraživanje klime u Potsdamu došao je do zaključka da je na području Balkana došlo do zastoja planetarnog vjetra jetstreama i Rossby-valova koji se u normalnim uvjetima kreću od sjevera prema jugu i obratno, a čije je zaustavljanje dovelo do pojave „zarobljene kiše“ (Slanjankić, 2016). Zastoj valova pripisali su klimatskim promjenama i smanjenju temperaturnih razlika između zračnih masa čime se kretanje valova onemogućilo (Slanjankić, 2016). Također, navode kako se ovakve pojave mogu sve češće očekivati o čemu govori porast broja ekstremnih kiša na Balkanu koje su se u zadnjih 60 godina udvostručile (Slanjankić, 2016).

\subsubsection{Reakcije na katastrofu i posljedice poplava}

Mnogi društveni akteri reagirali su na katastrofu, od volontera, medija, službi spašavanja, država u regiji do Europske unije i međunarodnih organizacija. Sarajevski Mediacentar analizirao je službene medije u $\mathrm{BiH}$ koji su izvještavali o poplavama i zaključeno je da su objave o opasnostima kasnile za društvenim mrežama te je uputama za djelovanje u slučaju izvanredne situacije pruženo malo medijskog prostora (Arnautović, 2014).

$\mathrm{Za}$ vrijeme poplava javio se veliki broj volontera koji su pritekli u pomoć ugroženom stanovništvu te je do izražaja došla solidarnost među ljudima koja je ujedinila regiju i obrisala etničke podjele karakteristične za BiH. Sociolog Slavo Kukić u svom komentaru na poplave istaknuo je: „U narodima na ovim prostorima nikada i nije bio problem, ali narodi su iskoristeni od strane političkih elita koje njima manipuliraju kako bi opstali na vlasti. Ali, u ova teška vremena kada su mnogi pogodeni poplavama, gradani svih nacija i vjera su pokazali da su spremni da pomognu drugima. Vidjeli smo mnoge lijepe primjere kada su ljudi spremni da pomognu drugom i drugačijem. Ljudi su pokazali da žele mectusobno da se potpomažu. Mislim da je najveci potencijal u tom socijalnom buntu koji se osjeti u BiH. Kada progovore ljudski stomaci, onda će se narodi ujediniti protiv političara." (Kukić, 2014 prema „Voda je izbrisala granice“, 2014). Osim solidarnosti, za vrijeme poplava javili su se problemi poput 
pljački napuštenih objekata, odbijanja evakuacije dijela stanovništva i lažni humanitarci koji su se predstavljali kao volonteri za prikupljanje pomoći (Balen, 2014).

Vlade država u regiji također su pokazale međusobnu suradnju. Oružane snage Republike Hrvatske i Hrvatska gorska služba spašavanja pritekle su u pomoć $\mathrm{BiH}$ (E. M., 2014). Osnovan je regionalni tim za djelovanje u kriznim situacijama i razminiranje („Osnovan regionalni tim“, 2014), a Vlada RH koordinirala je zahtjev za pomoć regiji iz Europskog fonda solidarnosti za države pogođene katastrofama (E. M., 2014). Pokrenut je i zajednički projekt zaprašivanja komaraca između RH, BiH i Srbije („Prihvaćen zajednički projekt", 2014). Najveći propust u koordiniranosti i organizaciji dogodio se između entiteta $\mathrm{BiH}$ koji se nisu mogli dogovoriti oko proglašenja elementarne nepogode na nivou države (E. M., 2014). Ipak, oba entiteta proglasila su Dan žalosti na isti dan, 20. svibnja. 2014. (E. M., 2014).

Za saniranje štete u BiH i Srbiji Europska komisija organizirala je donatorsku konferenciju „Obnovimo zajedno“ i u pomoć je priteklo više od 80 zemalja i međunarodnih organizacija („Za Srbiju i BiH 1,846 milijardi eura pomoći“, 2014). Na konferenciji je, između ostalog, istaknuta važnost prevencije sličnih događaja, potreba za razvojem infrastrukture riječnih tokova, nužnost razvoja hidroloških prognoza i regionalne suradnje („Za Srbiju i BiH 1,846 milijardi eura pomoći“, 2014). Veliki propust u sprečavanju poplava zbog loše infrastrukture dogodio se pucanjem nasipa u Rajevom Selu i Račinovcima u Hrvatskoj 17. svibnja što se nije smjelo dogoditi jer se radilo o novoizgrađenom nasipu (Patković i Mužević, 2014). U „Procjeni potreba za oporavkom i obnovom u Bosni i Hercegovini Poplave 14.-19. maj" navedeno je kako su efekti poplava bili pojačani zbog lošeg stanja okoliša u $\mathrm{BiH}$, uništenih riječnih korita, erozije tla nastale krčenjem šuma i objekata koji su izgrađeni na plavnim površinama (Vlada FBiH i sur., 2014:2). U svom osvrtu na poplave, Čaldarović je također ukazao na problem nepropisno izgrađenih objekata koji su zbog toga bili na udaru poplava i klizišta („Evo kako je došlo do katastrofalnih poplava“, 2014).

Najveći gubici od poplava ogledaju se u ljudskim žrtvama. U Hrvatskoj su stradale dvije osobe, u BiH 24, u Srbiji 51 osoba (RIMETEO, 2014). Dva smrtna slučaja povezana su s pomicanjem mina te jedan slučaj u kojem je osoba teško ranjena (Huseinović, 2014). Ukupna financijska šteta za $\mathrm{BiH}$ iznosila je 2,04 milijarde eura, gotovo 15\% BDP-a države (Vlada FBiH i sur., 2014:2). Pored velikih materijalnih gubitaka i mnogobrojnih opasnosti koje su se javile, kao što su opasnost od mina i zaraznih bolesti, najteže posljedice pretrpjeli su stanovnici poplavljenih područja gubitkom svojih domova i imovine. Kod ljudi su se javile psihološke posljedice te im je pružena psihološka pomoć (I. D., 2014). Razmjeri katastrofe koje su poplave ostavile za sobom u vidu gubitaka i trauma za stanovništvo usporedive su s ratnim posljedicama 1990-ih (Smajilhodžić, 2014).

\subsubsection{Zakonski akti o zaštiti i upravljanju vodama u BiH i Hrvatskoj}

U Hrvatskoj su na snazi Zakon o vodama (NN 153/09, 63/11, 130/11, 56/13, 14/14, 46/18) i Strategija upravljanja vodama (NN 91/2008). U BiH su na entitetskom nivou 2006. doneseni Zakon o vodama (Sl. glasnik RS 50/06, 92/09) u Republici Srpskoj i 
Zakon o vodama (Sl. novine FBiH 70/06) u Federaciji BiH. Oba entiteta imaju strategije upravljanja vodama, ali takva strategija ne postoji na državnoj razini. Zakoni o vodama u RH i BiH rađeni su prema „Okvirnoj direktivi EU o vodama“ (2000/60/EZ). Suradnja između entiteta u $\mathrm{BiH}$ u oblasti okoliša uređuje se specifičnim pravnim instrumentima, memorandumima o razumijevanju (Zavod za vodoprivredu Sarajevo i Mostar, 2012:90). Jedan od takvih memoranduma između vlada entiteta i Europske komisije prethodio je donošenju novih zakona o vodama u skladu s međunarodnim konvencijama i propisima Europske unije (Zavod za vodoprivredu Sarajevo i Mostar, 2012:91). Nedostatak ovakvih memoranduma je što nisu obvezujući i njihovo neprovođenje ne povlači sankcije čemu u prilog ide i neaktivnost osnovane Međuentitetske komisije za koordinaciju pitanja iz oblasti voda na temelju memoranduma (Zavod za vodoprivredu Sarajevo i Mostar, 2012:91).

$\mathrm{U}$ analizi poplava iz 2014. i institucionalnog okvira za upravljanje vodama u $\mathrm{BiH}$, Centri civilnih inicijativa iz Tuzle navode: „U Bosni i Hercegovini se neefikasno upravlja vodama, a postojeći institucionalni okvir za pitanja vezana za vode je decentralizovan, vrlo fragmentiran i heterogen, kako na entitetskom tako i na lokalnom nivou" (Deronja Suljić i sur., 2014:118). Najveću odgovornost za propuste u vrijeme poplava pripisuju entitetskom nivou vlasti jer su se najviše izlili primarni kanali koji su u nadležnosti entiteta (Deronja Suljić i sur., 2014:117). Također, kritiziraju nepostojanje mješovite specijalizirane jedinice za zaštitu i spašavanje između entiteta (Deronja Suljić i sur., 2014:55). Za koordinaciju civilne zaštite na državnoj razini zaduženo je Ministarstvo sigurnosti $\mathrm{BiH}$ te Koordinacijsko tijelo $\mathrm{BiH}$ za zaštitu i spašavanje, ali zbog nesuglasnosti među entitetima aktivnosti civilne zaštite su za vrijeme poplava ostale u domeni entiteta osim u primanju humanitarne pomoći (Deronja Suljić i sur., 2014:29,33).

\subsubsection{Diskusija}

Poplave iz 2014. ostavile su velike posljedice po regiju i njeno stanovništvo. U BiH i Hrvatskoj desili su se određeni operativni propusti pri čemu je do izražaja došla nepripremljenost za slične situacije. Najveći propust u Hrvatskoj bilo je pucanje novog nasipa u Račinovcima i Rajevu Selu, a naknadnim utvrđivanjem odgovornosti ustanovljeno je da su za njega odgovorni projektanti i izvođači radova (Molnar, 2014). U BiH glavne kritike upućene su lošoj organizaciji i nekoordiniranosti između entiteta što se ogleda u nepostizanju dogovora o proglašenju izvanredne situacije na državnom nivou. Dogovor između entiteta je kasnije uspostavljen zbog primanja humanitarne pomoći što svjedoči o tome kako se entiteti mogu dogovoriti kada za to postoji interes. Službeni mediji u $\mathrm{BiH}$ zakazali su u pravovremenom informiranju javnosti o nadolazećoj opasnosti te su njihovu ulogu preuzele društvene mreže. Mediji u slučaju akcidentalne situacije, javnosti trebaju pružiti jasne, brze i nedvosmislene informacije (Čaldarović, 2012:183) uz izbjegavanje senzacionalizma (Čaldarović, 2012:179). Osim u akcidentalnim situacijama, potrebno je educirati javnost i za vrijeme „normalnog stanja“ čime ih se priprema za slučaj katastrofe iako to ne znači da će se uvijek pridržavati zadanih uputstava (Čaldarović, 2012:189). 
Iako o poplavama govorimo kao o prirodnim rizicima koje prema Čaldaroviću ,javnost jednostavno uzima onakvima kakvi se povremeno pojavljuju, kao neizbježnu nužnost, neminovnost, 'usud', kao povremene događaje koji se ne daju izbjeći niti se njima može upravljati i na njihovo pojavljivanje, tok i posljedice utjecati" (Čaldarović, 1995:23) boljom prevencijom mogli su se reducirati razmjeri šteta koji su nastali. Također, uspostavljanjem međunarodne suradnje u zaštiti voda moguće je umanjiti posljedice sličnih katastrofa. Nakon poplava u BiH i Srbiji pokrenut je projekt rehabilitacije i modernizacije hidrološke i meteorološke mreže stanica i razmjene podataka između dviju država (Federalni hidrometeorološki zavod, 2017). Hrvatske vode i Državni hidrometeorološki zavod pokrenuli su projekt za unapređenje sustava prognoza poplava na slivu rijeke Save i njenih desnih pritoka u $\mathrm{BiH}$ te je uspostavljena suradnja između BiH i Hrvatske (Hrvatske vode, 2016).

BiH i Hrvatska trebaju unaprijediti svoju ekološku i vodnu politiku, izraditi adekvatnije planove upravljanja rizicima te sustav zaštite i obrane od poplava. Solidarnost i suradnja koju su volonteri, ali i državne vlasti pokazale pomažući se u kriznoj situaciji trebala bi se razvijati i inače, a ne samo u slučaju velikih katastrofa.

\subsection{Sedamnaesto jezero Plitvičkih jezera}

\subsubsection{Prekomjeran broj turista i nekontrolirana gradnja u NP-u Plitvička jezera}

Plitvička jezera prepoznata su po svojoj prirodnoj ljepoti mnogo prije nego ih je Socijalistička republika Hrvatska 1949. proglasila nacionalnim parkom (Ivanuš, 2010:127). Osim kao veliko prirodno blago, predstavljala su mogućnost za razvoj turizma te je prvi turistički objekt „Turistička kuća“ sagrađen davne 1862. (Ivanuš, 2010:124). Kroz povijest njihovog razvoja postojala su mnoga previranja između pobornika turističkog razvoja i pobornika zaštite prirode. Primjerice, nakon Prvog svjetskog rata dolazi do sukoba dviju struja o očuvanju Plitvičkih jezera, između botaničara Ive Pevaleka koji proučava biodinamiku jezera i Društva za uređenje i poljepšanje Plitvičkih jezera koje surađuje sa šumarskim inženjerom Antom Premužicém čijim se metodama za uređenje devastira priroda (Ivanuš, 2011, prema Knežević, 2014). Slična situacija događa se i poslije Drugog svjetskog rata kad u sukob dolaze dvije struje, organi za zaštitu prirode sa znanstvenicima s jedne strane i turistički djelatnici i ekonomisti s druge strane (Böhm, 1997:161).

Do 1970. u Parku su djelovala dva upravljačka tijela, Uprava Nacionalnog parka Plitvička jezera i Ugostiteljsko poduzeće Plitvice koja nisu bila koordinirana dok nije uspostavljena jedna uprava (Ivanuš, 2011, prema Knežević, 2014). Uspostavljanjem jedinstvene uprave unaprijeđena je zaštita prirode, a 1979. Park je uvršten na UNESCO-v popis svjetske prirodne baštine (Brlić i Bušljeta Tonković, 2017:187). Stavljanjem Parka na popis raste njegova popularnost, povećava se broj posjetitelja i u Titovoj Korenici buja gradnja uz nekontroliranu sječu šuma (Brlić i Bušljeta Tonković, 2017:187). Za vrijeme Domovinskog rata nacionalni park uvršten je na UNESCO-v popis Objekata ugrožene prirodne baštine (Böhm, 1997:163), a nakon rata UNESCO skreće pozornost na ugroženost nacionalnog parka privrednim aktivnostima (Böhm, 1997:164). 
Prema klasifikaciji Međunarodne unije za zaštitu prirode (IUCN) NP Plitvička jezera podijeljen je na zone prema prirodnim vrijednostima i načinu upravljanja. Od toga na zonu najstrože zaštite otpada 8,4\% površine Parka, 58,4\% na zonu stroge zaštite, 31,5\% na aktivnu zonu zaštite i 1,7\% površine na zonu upotrebe (Ružić i Šutić, 2014:244). Jezera spadaju u zonu upotrebe koja zauzima mali površinski prostor što Ružić i Šutić ističu kao veliki pritisak na ekosistem uz navođenje nelogične podijeljenosti Prošćanskog jezera na zonu najstrože zaštite i zonu upotrebe jer aktivnosti u jednoj zoni utječu na drugu (Ružić i Šutić, 2014:244).

Nakon Domovinskog rata broj posjetitelja od 800000 kao u periodu prije rata dosegnut je tek 2005. kad je vraćeno povjerenje u sigurnost posjete Hrvatskoj i Plitvičkim jezerima (Ružić i Šutić, 2014:242). Otada broj turista konstantno raste, čak do 1,3 milijuna posjetitelja godišnje (Lechpammer, 2016). Najveća koncentracija turista bilježi se od travnja do listopada, a više od 64\% posjetitelja Park posjećuje u srpnju, kolovozu i rujnu (Ružić i Šutić, 2014:242). U sezoni broj turista doseže i do 15000 dnevno dok je prema bivšem ravnatelju nacionalnog parka Anđelku Novoselu optimalan broj 8000 posjetitelja (Lechpammer, 2016). Na prevelik broj turista i devastaciju prirode reagira i UNESCO čija Reaktivna monitoring misija posjećuje Park početkom 2017. i iznosi niz zahtjeva među kojima je i izrada Akcijskog plana upravljanja posjetiteljima (D. I., 2017). Nakon procjene UNESCO-a Ministarstvo zaštite okoliša i energetike najavljuje smanjenje broja posjetitelja nakon što je pokrenuta izrada Akcijskog plana (D. I., 2017). Arhitekt Zdenko Strižić 1950. godine piše o turizmu koji bi trebao biti zastupljen na Plitvičkim jezerima: „dolazi u obzir mirni turizam koji se zasniva na obilju raspoloživog vremena... da se ne želi imati turizam koji hvata senzacije u što kraćem vremenu“" (Strižić, 1950, prema Ivanuš, 2010:128). Nažalost, situacija na Plitvičkim jezerima je upravo suprotna jer ih posjetioci doživljavaju kao usputno stajalište prema Jadranskom moru unatoč pokušajima uprave da ih animira na posjetu širem području parka (Ružić i Šutić, 2014:245).

Paralelno s rastom broja turista, na Plitvičkim jezerima rasli su problemi s izgradnjom smještajnih objekata. Iako su kroz povijest postojali planovi za smanjenje gradnje, primjerice „Program rada sa smjernicama zaštite, održavanja, prezentiranja, korištenja i promicanja Nacionalnog parka Plitvička jezera" koji odobrava Vlada RH 1993. kojim je bilo predviđeno premještanje hotela van Parka, Ministarstvo turizma rekonstruira postojeće objekte uz planiranje gradnje dodatnih sadržaja (Böhm, 1997:163,168). Noviji problemi s gradnjom odnose se na donošenje Prostornog plana 2014. pri čemu u obzir nisu uzete kritike Parka i Državnog zavoda za zaštitu prirode koji skreću pozornost na neprovođenje odrednica „Konvencije o zaštiti svjetske kulturne i prirodne baštine“ (Pariz, 1972) i ekološke mreže Natura 2000 (Pavelić, 2017). Mnogi aktivisti reagiraju na prostorni plan te ga Zelena akcija vidi kao dozvolu za pojačanu betonizaciju i komercijalizaciju (Arežina, 2014). UNESCO također reagira na pojačanu gradnju tražeći prekid izdavanja dozvola za gradnju i donošenje Strateške procjene utjecaja na okoliš koja je izostala u planu iz 2014. (UNESCO, 2016). 


\subsubsection{Infrastrukturni problemi NP Plitvička jezera; „sedamnaesto jezero“"}

Ekspanzijom turizma na Plitvičkim jezerima javili su se problemi s nedostatnom infrastrukturom za novonastale smještajne objekte. Do 1970-ih nije riješeno pitanje odvodnje, struje i vode, a infrastruktura bi trebala predstavljati osnov gradnje (Ivanuš, 2010:131). Otpadne vode izlijevale su se ispod hotela Plitvice u blizini jezera Kozjak kad bi se sustav začepio ili su završavale u vrtačama (Böhm, 1997:162). Kasnije je kanalizacijski sustav uz jezero Kozjak izgrađen do sela Rastovača, ali nepročišćene vode su i dalje završavale u vrtačama (Böhm, 1997:162). Ispitivanje kvalitete vode Bijele i Crne rijeke u nekoliko provedenih istraživanja pokazalo je zagađenost Bijele rijeke otpadnim vodama iz domaćinstava koje odlaze u Prošćansko jezero (Stilinović, 1979:84) te zagađenost Bijele rijeke fekalnim bakterijama (Vurnek i sur., 2016:43).

Jedna od posljedica neodržavanja i uništavanja prirode na Plitvičkim jezerima manifestirala se kroz pojavu eutrofikacije. Pribičević i suradnici opisali su eutrofikaciju kao prirodni proces starenja jezera, obogaćivanje vode hranjivim tvarima, ali koje može biti dodatno potaknuto ljudskim aktivnostima poput poljoprivrede, stočarstva, turizma i stvaranjem otpadnih voda te eutrofikaciju na Plitvičkim jezerima označavaju kao antropogenu (Pribičević i sur., 2007:2). Još jedna od posljedica je gubitak vode iz jezera Kozjak uzrokovan eksploatacijom (Biondić i sur., 2010:197) na što se osvrnuo i UNESCO tražeći premještanje vodocrpilišta (M. Ž., 2016).

Nepročišćavanje vode predstavlja veliki nedostatak sustava odvodnje u nacionalnom parku. Novosel navodi kako je nakon rata 90-ih izgrađen kolektorski sustav koji spaja nekoliko naselja, ali bez pročistača, iako je njegova gradnja bila planirana 1989., dok otpadne vode koje se ne pročǐšćavaju teku u vrtaču u naselju Rastovača (Ćurić, 2016). Nakupljanje vode u vrtači dovelo je do formiranja takozvanoga ,sedamnaestog jezera“ Plitvičkih jezera. Ovaj problem svoj medijski prostor dobiva 2014. u emisiji HRT-a „Što vas žulja?" u kojoj su o vrtači govorili stanovnici Rastovače. Pažnju na problem skreću i ekološke udruge pa tako Zelene stope vrtaču opisuju kao „najveću otvorenu septičku jamu u Hrvatskoj" (Ibrišević, 2015). Uprava nacionalnog parka svjesna je problema na koji se osvrnula i bivša ravnateljica Natalija Božičević tvrdeći kako Park svake godine radi na čišćenju jame te da Hrvatske vode, ministarstva i NP zajednički rade na proširenju kolektorskog sustava (ABC TV, 2014).

Međutim, problem se dodatno usložnjava jer otpadne vode iz Rastovače teku prema slivu rijeke Une u BiH (Ćurić, 2016). U istraživanju tokova podzemnih voda proveden je eksperiment bojanja koji je pokazao da boja ubačena u blizini jezera izbija na izvoru Klokot u BiH koje je udaljeno 17,6 km od mjesta ubacivanja boje (Biondić i sur., 2010:203). S ovog izvora vodu za piće koristi više desetaka tisuća stanovnika Bihaća što čini veliki rizik po zdravlje ljudi („Prekogranični ekološki problem“, 2014). RH i BiH počele su surađivati u cilju rješavanja ovog problema pokretanjem projekta zaštite izvora Klokot u kojem učestvuju poduzeće Una Consulting i druge institucije u $\mathrm{BiH}$ u suradnji s Hrvatskim vodama uz osnivanje međunarodne Komisije za revidiranje projekta (Vojić, 2017). Glavni problem s hrvatske strane, kako ističe Novosel, bio je u Zakonu o 
vodama prema kojem ,javna ustanova ne može niti biti nositelj infrastrukturnih projekata ciji je cilj izgradnja vodoopskrbe i odvodnje“ (Novosel, 2017, prema Blaško, 2017). Kako bi se izvršila rekonstrukcija sustava, 2017. sustav vodoopskrbe i odvodnje prebačen je s Javne ustanove na Vodovod Korenica (S. Ve., 2017). Projekt rekonstrukcije započeo je tek nakon posjete UNESCO-a Plitvičkim jezerima što govori o nedostatku volje nadležnih institucija da problem samostalno riješe.

\subsubsection{Zaštita prirode u BiH i Hrvatskoj}

U Hrvatskoj je Zakonom o zaštiti prirode (NN 80/13, 15/18, 14/19) zaštićeno 8,56\% državnog teritorija, odnosno 420 područja kojima upravljaju javne ustanove $s$ planovima upravljanja od deset godina (Ministarstvo zaštite okoliša i energetike RH, 2018). Središnja stručna ustanova za zaštitu prirode je Hrvatska agencija za okoliš i prirodu. Problem u upravljanju zaštićenim područjima u Hrvatskoj predstavlja činjenica da je $35 \%$ zemljišta zaštićenih područja u privatnom vlasništvu (Državni zavod za zaštitu prirode, 2014:303).

U BiH su zakoni za zaštitu prirode doneseni na nivou entiteta. Za sprovođenje međunarodnih obveza nadležno je Ministarstvo vanjske trgovine i ekonomskih odnosa $\mathrm{BiH}$ i Ministarstvo civilnih poslova $\mathrm{BiH}$, a za koordinaciju među entitetima Međuentitetsko tijelo za zaštitu životne sredine (Republički zavod za zaštitu kulturno-istorijskog i prirodnog nasljeđa RS, 2016). Što se tiče agencija za zaštitu prirode, u FBiH ukinut je Zavod za zaštitu kulturnog i prirodnog naslijeđa BiH (Variščić, 2012:23), a u RS-u djeluje Republički zavod za zaštitu kulturno-istorijskog i prirodnog nasljeđa. Donošenjem novog Zakona o zaštiti prirode $\mathrm{FBiH}$ (Sl. novine $\mathrm{FBiH}$ 66/13) najavljeno je osnivanje Federalnog zavoda za zaštitu prirode koji bi provodio zakon (F.M., 2013), ali u „Programu rada Vlade Federacije $\mathrm{BiH}$ za 2018. godinu" ponovno se ističe potreba za osnivanjem Federalne agencije za okoliš i Federalnog zavoda za zaštitu prirode (Vlada FBiH, 2018:261). U BiH zaštićeno je $1,96 \%$ teritorija što je ocijenjeno nedovoljnim u odnosu na zemlje u regiji i svijetu (Ministarstvo vanjske trgovine i ekonomskih odnosa $\mathrm{BiH}$ i sur., 2016:71).

\subsubsection{Diskusija}

Nacionalni park Plitvička jezera zapošljava 650 stalnih radnika i 450 dodatnih radnika u sezonskim mjesecima (Kovačević, 2017). Time predstavlja važan izvor prihoda Ličko-senjske županije uz turizam kojim se bavi lokalno stanovništvo. Iako Park sam proizvodi 99,99\% prihoda (Ružić, 2011) i neovisan je od državnih poticaja, u isto vrijeme omogućen je prevelik razvoj turizma kojim se narušava zaštita prirode. $S$ druge strane, prisutan je nedostatak političkog sluha za očuvanje prirode što je vidljivo u izjavi bivšeg ministra turizma Antona Klimana da je posao Ministarstva turizma da dovodi goste u Hrvatsku, a Ministarstva zaštite okoliša da štiti prirodu (M. B., 2016). Ovakva izjava zabrinjava jer dolazi od predstavnika državne institucije koja bi trebala voditi računa o zaštiti nacionalnog parka. Prema Cifriću, konflikt između privatnog vlasništva nad prirodnim dobrima i javnog prava potrebno je riješiti kroz „regulaciju obveza privatnog vlasništva na poštovanje ekoloških normi, a s druge strane da se zaštiti privatno vlasništvo od negativnih internih 
i eksternih utjecaja razvlašćivanja“ (Cifrić, 2002:149). Također je potrebno razviti bolju politiku nadležnih institucija prema zaštićenim područjima.

„Rak-rana“ nacionalnog parka, kako se u novinskim napisima opisuje sustav vodoopskrbe i odvodnje na Plitvičkim jezerima (Blaško, 2017), svoju kritičnu točku doseže u stvaranju „sedamnaestog jezera“ u naselju Rastovača čije podzemne vode zagađuju izvor pitke vode u BiH. Suradnja između BiH i Hrvatske u zaštiti izvora Klokot pokrenuta je, ali ukoliko se ne poduzmu koraci za rješavanje ostalih problema u Parku, poput pretjerane gradnje, trend zagađenja nastavit će se. Prema Tišmi i suradnicima, naslijeđeni masovni turizam teško se može izbjeći, ali kvalitetna turistička ponuda i pojačana kontrola nad upotrebom prirodnih resursa može ublažiti njegove posljedice (Tišma i sur., 2006:107,116).

Zakoni o zaštiti prirode deklarativno postoje u $\mathrm{BiH}$ i Hrvatskoj, ali je upitno koliko se primjenjuju. U pogledu regionalnih razlika u upravljanju zaštićenim područjima, Slovenija i Hrvatska stoje bolje u odnosu na Srbiju, Crnu Goru i Albaniju, a BiH i Kosovo ocijenjene su najlošije (Lindenmann i sur., 2011:23). Najmlađi nacionalni park u BiH, Una, s Plitvičkim jezerima dijeli blisko geografsko područje i međusobna česta suradnja trebala bi se dodatno poticati (Lindenmann i sur., 2011:41). Suradnja među državama u zaštiti prirode podjednako je važna kao i savjesno upravljanje zaštićenim područjima unutar pojedinačnih država.

\section{ZAKLJUČAK}

Najvažnija je karakteristika prekograničnog zagađenja da ono ne poznaje umjetno konstruirane teritorijalne i nacionalne granice kao što su pokazale i tri studije slučaja prekograničnog zagađenja između Hrvatske i Bosne i Hercegovine. Analiza političkog i društvenog konteksta pojedinačnih država na koje se odnosi prekogranično zagađenje izrazito je važna kako bismo shvatili na koji način se države odnose prema ovakvoj vrsti zagađenja i na koji ga način rješavaju.

U slučaju zagađenja zraka u Slavonskom Brodu možemo zaključiti da ekonomski interesi imaju prevagu nad zaštitom okoliša i očuvanjem ljudskog zdravlja. Vlada Republike Srpske pogoduje ruskim vlasnicima Rafinerije zbog stvaranja profita te prilagođava zakone i izdaje okolišne dozvole bez uzimanja u obzir štete koju zagađenje uzrokuje. Osim toga, Rafinerija predstavlja važan izvor prihoda entiteta Republike Srpske te na primjeru Bosne i Hercegovine možemo primijeniti tezu Ulricha Becka o sistemskom privlačenju između ekstremnog siromaštva i ekstremnih rizika (Beck, 2001:62). S obzirom na egzistencijalnu sigurnost koju Rafinerija pruža lokalnom stanovništvu, ne iznenađuje zanemarivanje aspekta očuvanja okoliša i prihvaćanje zagađenja. S druge strane, Rafinerija dugi niz godina ugrožava zdravlje ljudi i okoliš preko granice u Slavonskom Brodu. Iako postoje mnogobrojni pokušaji Vlade $\mathrm{RH}$ da se zagađenje zaustavi, činjenica da nafta u Rafineriju stiže hrvatskim naftovodom JANAF-om ponovno govori o pogodovanju ekonomskim akterima na štetu građana. Najavljena plinofikacija predstavlja pomak k 
rješenju problema iako se mogla provesti mnogo ranije da je za to postojala politička volja. Osim toga, sama plinofikacija ne predstavlja cjelokupno rješavanje problema $s$ obzirom na vrstu nafte koja se prerađuje u postrojenju. Također, u Slavonskom Brodu potrebno je riješiti pitanje lokalnih zagađivača jer, kao što Merrill ističe, ugrožena država ne bi trebala zahtijevati od stanovnika druge države više no što zahtijeva od vlastitih građana (Merrill, 1997:1018).

U slučaju poplava koje su pogodile regiju u svibnju 2014. možemo zaključiti kako je do izražaja došla nepripremljenost država u regiji za slične situacije, naročito u $\mathrm{BiH}$. Osim lošeg upravljanja rizicima od ekoloških katastrofa, poplave su ukazale na problem slabe brige o okolišu, neadekvatno izgrađenih nasipa, slabe prevencije i vodne politike što je uvećalo razmjere katastrofe. Razvoj hidroloških i meteoroloških prognoza nakon poplava pokazuje kako su države mogle biti bolje pripremljene da su se ove prognoze ranije razvile. Veliki problem u $\mathrm{BiH}$ predstavljala je i nekoordiniranost između entiteta koji su se nisu mogli dogovoriti oko proglašenja vanredne situacije na državnom nivou. Kao što zagađenje zraka ne poznaje političke granice, isto tako rijeke koje su se izlile iz svojih korita podsjećaju na potrebu suradnje među državama u prevenciji sličnih događaja. $\mathrm{Na}$ solidarnost koju su ljudi pokazali tijekom katastrofe trebali bi se ugledati i predstavnici političkih institucija.

Slučaj zagađenja izazvan neriješenim sustavom odvodnje u najvećem nacionalnom parku u Hrvatskoj govori o tome kako želja za što većim profitom i razvojem turizma prevladavaju nad očuvanjem prirode koje bi trebalo biti glavna svrha nacionalnog parka. To potvrđuje Čaldarovićevu tvrdnju kako se umjesto mjerenja uspješnosti turističkog mjesta kroz kvalitetno očuvanje sredine ono mjeri kroz broj noćenja (Čaldarović, 2012:16). „Sedamnaesto jezero“ Plitvičkih jezera istodobno ugrožava život stanovnika naselja Rastovače, ali i njenih regionalnih susjeda u BiH. Tek intervencijom UNES$\mathrm{CO}-\mathrm{a}$ pokrenuto je pitanje vodoopskrbe i odvodnje u nacionalnom parku, prekomjernog broja turista i nekontrolirane gradnje. Smjernice koje je UNESCO dao Plitvičkim jezerima predstavljaju tek ukazivanje na problem koje bez adekvatne primjene u praksi ne znače mnogo. Prevrednovanje nacionalnog parka u njegovu prvobitnu svrhu nužno je za očuvanje prirode i zaustavljanje loših trendova na Plitvičkim jezerima od kojih podjednako pate priroda i ljudi.

Upravljanje rizicima zagađenja i prekograničnog zagađenja okoliša u Hrvatskoj i $\mathrm{BiH}$ potrebno je unaprijediti uz primjenu odgovarajućih strategija na državnom i međudržavnom nivou. Iako postoje, mnogobrojni zakoni koji se tiču zaštite okoliša i preuzete direktive Europske unije u najvećem broju slučajeva ostaju samo ispunjavanje pravnih formalnosti. U obje države nedostaje praktičnih mjera i sankcija za zagađenje. Osim toga, potrebna je dodatna edukacija građana, političara i poduzetnika o važnosti očuvanja okoliša i posljedicama koje nedovoljna briga o njemu može izazvati. 


\section{LITERATURA}

ABC TV (2014). Ekološki problem nadomak Bihaća: Sedamnaesto jezero Plitvičkih jezera direktno truje građane Bihaća? Emisija „Što vas žulja?" Hrvatske radiotelevizije, 23. listopada 2014. [Video prilog] URL: https://www.youtube.com/watch?v=lokmy6k814M (12.11.2018.)

A. H. (2013). Usvojen dokument „Velika pobjeda za Dinarski luk“. energetika-net, 4. prosinca 2013. URL: http://www.energetika-net.com/vijesti/zastita-okolisa/usvojen-dokument- velika-pobjeda-za-dinarski-luk-17931 (12.11.2018.)

Alarmantno onečišćenje u Slavonskom Brodu Građani već dižu ruke od svega: „Svjesni smo da se ništa neće promijeniti“ (2016). Jutarnji list, 13. siječnja 2016. URL: https://www.jutarnji.hr/vijesti/hrvatska/alarmantno-oneciscenje-u-slavonskom-brodu-gradani-vec-dizu-ruke-od-svega-svjesni-smo-da-se-nista-nece-promijeniti/86362/ (12.11.2018.)

Arežina, B. (2014). Zelena akcija ispred Sabora prosvjedovala protiv betonizacije Plitvica. Večernji list, 28. ožujka 2014. URL: https://www.vecernji.hr/vijesti/zelena-akcija- ispred-sabora-prosvjedovala-protiv-betonizacije-plitvica-929649 (12.11.2018.)

Arnautović, A. (2014). Internet je ukrao medije. Mediacentar Sarajevo, 20. svibnja 2014. URL: http://www.media.ba/bs/novinarstvo-mreze-i-web/internet-je-ukrao-medije (12.11.2018.)

Balen, V. (2014). Lažni humanitarci traže novac za stradale u poplavama. Večernji list, 19. svibnja 2014. URL: https://www.vecernji.hr/vijesti/lazni-humanitarci-traze-novac-za- stradale-u-poplavama-939535 (12.11.2018.)

Balen, V. (2015). U Europskom parlamentu o kvaliteti brodskog zraka. Večernji list, 6. svibnja 2015. URL: https://www.vecernji.hr/vijesti/u-europskom-parlamentu-o-kvaliteti- brodskog-zraka-1003984 (12.11.2018.)

Beck, U. (2001). Rizično društvo: u susret novoj moderni. Beograd: Filip Višnjić.

$\mathrm{BiH}: 1,5$ milijuna ljudi pogođeno poplavama, nužna pomoć u obnovi (2014). Hrvatska radiotelevizija, 22. svibnja 2014. URL: http://vijesti.hrt.hr/245188/bih-prijete-klizista- mine-i-zarazne-bolesti-srbija-ceka-se-vrhunac-vodenog-vala (12.11.2018.)

BiH nema strategiju održivog razvoja (2017). Dnevni list, 3. travnja 2017. URL: https:// dnevni-list.ba/bih-nema-strategiju-odrzivog-razvoja/ (12.11.2018.)

Biondić, B., Biondić, R. i Meaški, H. (2010). The conceptual hydrogeological model of the Plitvice Lakes. Geologia Croatica, 63(2): 195-206.

Blaško, D. (2017). Neviđena sramota na Plitvicama: „Problem treba hitno riješiti, to je ekološka bomba!“ Dnevnik.hr, 10. veljače 2017. URL: https://dnevnik.hr/ vijesti/hrvatska/plitvickim-jezerima-plivaju-fekalije-problem-treba-hitno-rijesiti-to-je-ekoloska- bomba---466512.html (12.11.2018.)

Brlić, I. i Bušljeta Tonković, A. (2017). The Origins and Developmental Course of the Plitvice Lakes National Park: From „The Devil's Garden“ to the UNESCO World Natural Heritage Register. U: Petrić, H. i Žebec Šilj, I. (ur.), Environmentalism in Central and Southeastern Europe: Historical Perspectives (str. 175-196). Lanham, Maryland: Lexington Books 
Brođani pripremaju ekološku tužbu protiv JANAF-a (2017). eZadar.hr, 19. ožujka 2017. URL: https://ezadar.rtl.hr/dogadaji/2650895/brodjani-pripremaju-ekolosku-tuzbu-protiv- janaf-a/ (12.11.2018.)

Böhm, D. (1997). Aktualni problem zaštite i očuvanja Nacionalnog parka Plitvička jezera. Šumarski list, 121(3-4): 161-170.

Carter, N. (2004). Strategije zaštite okoliša: ideje, aktivizam, djelovanje. Zagreb: Barbat.

Cifrić, I. (2002). Okoliš i održivi razvoj: ugroženost okoliša i estetika krajolika. Zagreb: Hrvatsko sociološko društvo, Zavod za sociologiju Filozofskog fakulteta.

Cifrić, I. (2012). Leksikon socijalne ekologije: kritičko promišljanje. Zagreb: Školska knjiga.

Čaldarović, O. (1995). Socijalna teorija i hazardni život: rizici i suvremeno društvo. Zagreb: Hrvatsko sociološko društvo, Zavod za sociologiju Filozofskog fakulteta.

Čaldarović, O. (2012). Prema društvu uspješno reguliranog rizika? Zagreb: Hrvatsko sociološko društvo, Zavod za sociologiju Filozofskog fakulteta.

Ćumurović, D. (2017). Zvizdić reagovao na potpisivanje protokola između Hrvatske i RS-a: Pitanje plina nikada ne uključuje interese samo jedne strane. Oslobodenje, 1. studenoga 2017. URL: https://www.oslobodjenje.ba/vijesti/bih/zvizdic-reagovao-na-potpisivanje-protokola-izmedu-hrvatske-i-rs-a-pitanje-plina-nika-

da-ne-ukljucuje- interese-samo-jedne- strane?fb_comment_id=147015544643291 6_1470201186428342 (23.12.2018.)

Ćurić, D. (2016). Gradnja apartmana i uriniranje po Plitvicama moraju stati. Večernji list, 23. srpnja 2016. URL: https://www.vecernji.hr/vijesti/gradnja-apartmana-i-uriniranje-po- plitvicama-moraju-stati-1101274 (12.11.2018.)

Deronja Suljić, L., Bulić, M., Telić, D. i Ćilimković, A. (2014). Poplave u BiH Elementarne nepogode i / ili institucionalna neefikasnost. Radna verzija. Tuzla: Centri civilnih inicijativa. URL: http://www.cci.ba/dokumenti/Analiza_B5.pdf (12.11.2018.)

Direktiva 2000/60/EZ Europskog parlamenta i Vijeća od 23. listopada 2000. o uspostavi okvira za djelovanje Zajednice u području vodne politike, Službeni list Europske unije, 327/1, 15(1): 48-119.

Direktiva 2001/42/EZ Europskog parlamenta i Vijeća od 27. lipnja 2001. o procjeni učinaka određenih planova i programa na okoliš, Službeni list Europske unije, 197/30, 15(13): 17-24.

Direktiva 2001/81/EZ Europskog parlamenta i Vijeća od 23. listopada 2001. o nacionalnim gornjim granicama emisije za određene onečišćujuće tvari, Službeni list Europske unije, 309/22, 15(29): 54-62.

Direktiva 2007/60/EZ Europskog parlamenta i Vijeća od 23. listopada 2007. o procjeni i upravljanju rizicima od poplava, Službeni list Europske unije, 288/27, 15(1): 186-193.

Direktiva 2010/75/EU Europskog parlamenta i Vijeća od 24. studenoga 2010. o industrijskim emisijama (integrirano sprečavanje i kontrola onečišćenja, Službeni list Europske unije, 334/17, 15(15): 159-261.

D. I. (2017). UNESCO ove godine neće Plitvice staviti na popis ugroženih područja. Dnevnik.hr, 29. ožujka 2017. URL: https://dnevnik.hr/vijesti/hrvatska/unes- 
co-ove-godine-nece-plitvice-staviti-na-popis-ugrozenih-podrucja---471485.html (12.11.2018.)

Državni zavod za zaštitu prirode (2014). Izvješće o stanju prirode u Republici Hrvatskoj za razdoblje 2008.-2012. Nacrt.

Ekonomska komisija Ujedinjenih naroda za Europu (2011). Pregled stanja okoliša Bosna i Hercegovina. New York i Ženeva: Ujedinjeni narodi

E. M. (2014). Kaos u BiH: Milijun ljudi pogođeno poplavama, uništeno 100.000 kuća. Index.hr, 19. svibnja 2014. URL: http://www.index.hr/vijesti/clanak/kaos-u-bih-milijun-ljudi-pogodjeno-poplavama-unisteno-100000-kuca/748188.aspx (12.11.2018.)

Evo kako je došlo do katastrofalnih poplava (2014). Net.hr, 19. svibnja 2014. URL: https:// net.hr/danas/hrvatska/evo-kako-je-doslo-do-katastrofalnih-poplava/ (12.11.2018.)

Federalni hidrometeorološki zavod (2017). O realizaciji regionalnog projekta „Rehabilitacija i modernizacija hidrološke i meteorološke mreže stanica i procedura razmjene podataka u Bosni i Hercegovini i Srbiji“ - pomoć Vlade Finske, implementira Meteorološki zavod Finske. Saopštenjelinformacija. Sarajevo, 11. siječnja 2017. URL: http://www.fhmzbih.gov.ba/podaci/novosti/saopstennje-FinskiProjekat.pdf (12.11.2018.)

F. M. (2013). U FBiH se uspostavlja Zavod za zaštitu prirode. Novo vrijeme, 28. srpnja 2013. URL: http://novovrijeme.ba/u-fbih-se-uspostavlja-zavod-za-zastitu-prirode/ (12.11.2018.)

Galović, I. (2014). Održan 2. sastanak Povjerenstva za praćenje poboljšanja kvalitete zraka na području Slavonskog Broda. Večernji list, 22. prosinca 2014. URL: https:// www.vecernji.hr/vijesti/odrzan-2-sastanak-povjerenstva-za-pracenje- poboljsanja-kvalitete-zraka-na-podrucju-slavonskog-broda-980746 12.11.2018.

Giddens, A. (2007). Sociologija. Zagreb: Nakladni zavod Globus.

Granić, G., Zeljko, M., Moranjkić, I., Andres Martinez, J., Olano, M. i Jurić, Ž. (2008). Studija energetskog sektora u BiH. Konačni izvještaj. Modul 13 - Okoliš. Zagreb: Energetski institut Hrvoje Požar.

Gvozdić, V., Brana, J., Malatesti, N., Puntarić, D., Vidosavljević, D. i Roland, D. (2011). An

Analysis of the Pollution Problem in Slavonski Brod (Eastern Croatia). Collegium Antropologicum, 35(4):1135-1141.

Hrvatska agencija za okoliš i prirodu (2018). Kvaliteta zraka u Republici Hrvatskoj. URL: http://iszz.azo.hr/iskzl/ (23.12.2018.)

Hrvatska: Plinofikacija rafinerije u Brodu nema alternative (2018). Al Jazeera Balkans, 10. listopada 2018. URL: http://balkans.aljazeera.net/vijesti/hrvatska-plinofikacija- rafinerije-u-brodu-nema-alternative (23.12.2018.)

Hrvatske vode (2016). Dovršen cjeloviti hidrološko-hidraulički model za sliv rijeke Save do granice s Republikom Srbijom. 28. srpnja 2016. URL: http://www.voda.hr/hr/ novosti/ dovrsen-cjeloviti-hidrolosko-hidraulicki-model-za-sliv-rijeke-save-do-granice-s- republikom (12.11.2018.) 
Huseinović, S. (2014). Protuminsko djelovanje nakon poplava. Deutsche Welle, 17. rujna 2014. URL: http://www.dw.com/hr/protuminsko-djelovanje-nakon-popla$\mathrm{va} / \mathrm{a}-17925865$ (12.11.2018.)

Ibrišević, R. (2015). Otkriveno novo ,jezero“ na Plitvicama: Gledati samo na prazan želudac. Dnevnik.hr, 30. prosinca 2015. URL: https://dnevnik.hr/vijesti/hrvatska/ zagadjenje-na-plitvickim-jezerima-kolika-je-zapravo-steta-od-turista---421398.html (12.11.2018.)

I. D. (2014). Prihvatilišta puna: Evakuiranima prijeti opasnost od crijevnih zaraznih bolesti. Dnevnik.hr, 20. svibnja 2014. URL: https://nnevnik.hr/vijesti/hrvatska/katastrofalne- poplave-tisuce-evakuiranih---336850.html (12.11.2018.)

I. M. (2009). Rafinerija iz Bosanskog Broda uporno zagađuje zrak u Slavonskom Brodu. Index.hr, 10. ožujka 2009. URL: http://www.index.hr/vijesti/clanak/rafinerija-iz- bosanskog-broda-uporno-zagadjuje-zrak-u-slavonskom-brodu/424734.aspx (12.11.2018.)

Institut za hidrotehniku Građevinskog fakulteta u Sarajevu (2013). Preliminarna procjena poplavnog rizika na vodotocima I kategorije u FBiH. Sarajevo: Institut za hidrotehniku Građevinskog fakulteta u Sarajevu.

Ivanuš, M. (2010). Vrednovanje turističke izgradnje na području Plitvičkih jezera. Prostor, 18 1(39): 122-135.

J. K. (2017). Vijeće ministara: Usvojena Strategija zaštite okoliša. Radio-televizija Bosne i Hercegovine, 30. svibnja 2017. URL: http://www.bhrt.ba/vijesti/bih/vijece-ministara- usvojena-strategija-zastite-okolisa/ (29.4.2018.)

Jovičić, B. (2017). BiH menja ekološke dozvole za dve nove elektrane da bi ispoštovala direktivu EU. Balkan Green Energy News, 12. prosinca 2017. URL: https://balkangreenenergynews.com/rs/bih-menja-ekoloske-dozvole-dve-nove- elektrane-ispostovala-direktivu-eu/ (12.11.2018.)

Kaštelan-Macan, M. (2010). O neusklađenosti hrvatskih naziva u zaštiti okoliša. Kemija u industriji, 59(11): 547-549.

Kelava, M. (2011). Zrak smrdi, vazduh čist. H-Alter, 18. veljače 2011. URL: http://halter.org/vijesti/zrak-smrdi-vazduh-cist (12.11.2018.)

Knezović, G. (2006). Dolazak Zarubežnjefta na Balkan mijenja tržišne odnose. Poslovni dnevnik, 31. kolovoza 2006. URL: http://www.poslovni.hr/hrvatska/dolazak- zarubeznjefta-na-balkan-mijenja-trzisne-odnose-20881 (12.11.2018.)

Knezović, G. (2007). Brodska Rafinerija želi osvojiti regionalna tržišta. Poslovni dnevnik, 5. prosinca 2007.URL: http://www.poslovni.hr/after5/brodska-rafinerija-zeli-osvojiti- regionalna-trzista-62926 (12.11.2018.)

Knežević, S. (2014). Baština, mi i svijet 8. lipnja 2014. HRT, 6. lipnja 2014. URL: http://radio.hrt.hr/clanak/bastina-mi-i-svijet-8lipnja-2014/59387/ (12.11.2018.)

Komatina, D., Zlatić-Jugović, J. (2010). Prekogranična suradnja u slivu rijeke Save u oblasti upravljanja vodama. Hrvatske vode, 18(73): 249-258.

Konvencija o biološkoj raznolikosti (Rio de Janeiro, 1992), Službeni glasnik BiH - Medunarodni ugovori, 12/02; Narodne novine - Mecunarodni ugovori, 6/96. 
Konvencija o prekograničnom onečišćenju zraka na velikim udaljenostima (Geneva, 1979), Službeni list RBiH, 13/94; Narodne novine - Mecunarodni ugovori, 12/93.

Konvencija o prekograničnim učincima industrijskih nesreća (Helsinki, 1992), Službeni glasnik BiH-Medunarodni ugovori, 16/12; Narodne novine-Medunarodni ugovori, 7/1999.

Konvencija o pristupu informacijama, sudjelovanju javnosti u odlučivanju i pristupu pravosuđu u pitanjima okoliša (Aarhus, 1998), Službeni glasnik BiH-Mectunarodni ugovori, 08/08; Narodne novine - Međunarodni ugovori, 1/07.

Konvencija o procjeni utjecaja na okoliš preko državnih granica (Espoo, 1991), Službeni glasnik BiH - Medunarodni ugovori, 08/09; Narodne novine-Medunarodni ugovori, $6 / 96$.

Konvencija o suradnji na zaštiti i održivoj uporabi rijeke Dunav (Sofija, 1994), Službeni glasnik BiH, 65/05; Narodne novine - Medunarodni ugovori, 02/1996.

Konvencija o zaštiti europskih divljih vrsta i prirodnih staništa (Bern, 1979), Službeni glasnik BiH-Medunarodni ugovori, 08/08; Narodne novine-Medunarodni ugovori, $6 / 00$

Konvencija o zaštiti i uporabi prekograničnih vodotoka i međunarodnih jezera (Helsinki, 1992), Službeni glasnik BiH, 8/09; Narodne novine - Medunarodni ugovori, 4/1996.

Konvencija o zaštiti svjetske kulturne i prirodne baštine (Pariz, 1972), Službeni list RBiH, 25/93; Narodne novine - Medunarodni ugovori, 12/93.

Kovačević, R. (2017). „Plitvička jezera su poput vlaka koji juri prema ponoru“. Večernji list, 4. studenoga 2017. URL: https://www.vecernji.hr/vijesti/andjelko-novosel-plitvicka- jezera-1205550 (12.11.2018.)

Lacić, S. i Mikulić, I. (2018). Štern: Plinofikacija Rafinerije Brod neće u cijelosti riješiti problem onečišćenja. Glas Slavonije, 11. listopada 2018. URL: http://www.glasslavonije.hr/378393/1/Stern-Plinofikacija-Rafinerije-Brod-nece-u-cijelosti-rijesitiproblem-oneciscenja (23.12.2018.)

Lechpammer, S. (2016). Ugrozili Plitvička jezera i Dubrovnik, UNESCO prijeti sankcijama. Večernji list, 26. rujna 2016. URL: https://www.vecernji.hr/lifestyle/ugrozili-plitvicka- jezera-i-dubrovnik-unesco-prijeti-sankcijama-1116407 (12.11.2018.)

Lindenmann, K., Rajković, Ž. i Škunca, O. (2011). Plitvice Lakes National Park - Croatia and Una National Park - Bosnia and Herzegovina: Assessment on the feasibility study of establishing transboundary cooperation. Gland i Beograd: IUCN Programme Office for South-Eastern Europe.

Maglajlija, V. (2017). Rafinerija u Brodu dobija plin iz Hrvatske bez saglasnosti BiH. Al Jazeera Balkans, 14. listopada 2017. URL: http://balkans.aljazeera.net/vijesti/ rafinerija-u-brodu-dobija-plin-iz-hrvatske-bez- saglasnosti-bih (12.11.2018.)

M. B. (2016). Plitvička jezera mogla bi biti izbrisana s liste UNESCO-a. Dnevnik. $h r$, 12. srpnja 2016. URL: https://dnevnik.hr/vijesti/hrvatska/plitvicka-jezera-mogla-bi-biti- izbrisana-s-liste-unesco-a---443090.html (12.11.2018.)

Međunarodna komisija za sliv rijeke Save (2014). Poplava u svibnju 2014.: Najveća poplava u regiji u poznatoj povijesti. 21. svibnja 2014. URL: http://www.sa- 
vacommission.org/index.php?idnews=148\&l=bhhr\&page=news_detail\&pgn=2 (12.11.2018.)

Merrill, T. W. (1997). Golden Rules for Transboundary Pollution. Duke Law Journal, 46(5): 931-1019.

Ministarstvo turizma Republike Hrvatske (2015). Potpisana „Deklaracija mreže Sava Parks“. 2. veljače 2015. URL: http://www.mint.hr/vijesti/potpisana-deklaracijamreze-sava- parks/8878 (12.11.2018.)

Ministarstvo vanjskih i europskih poslova Republike Hrvatske (2014). Poplave u Hrvatskoj i regiji - analiza situacije na dan 28. svibnja 2014. Priopćenje,30. svibnja 2014. URL: http://www.mvep.hr/hr/mediji/priopcenja/poplave-u-hrvatskoj-i-regiji-analiza-situacije-na-dan-28-svibnja-2014-,21661.html (12.11.2018.)

Ministarstvo zaštite okoliša i energetike Republike Hrvatske (2014). Utvrđeni izvori onečišćenja zraka u Slavonskom Brodu, ključni za poduzimanje konkretnih mjera za rješavanje problema. Priopćenje za javnost, 22. prosinca 2014. URL: http://www.mzoip.hr/ $\mathrm{hr} /$ ministarstvo/vijesti/utvrdeni-izvori-oneciscenja-zraka-u- slavonskom-brodu-kljucni-za-poduzimanje-konkretnih-mjera-za-rjesavanje- problema.html (12.11.2018.)

Ministarstvo zaštite okoliša i energetike Republike Hrvatske (2016). Održan sastanak međudržavne Radne grupe za praćenje stanja zraka u Slavonskom Brodu i Brodu. Priopćenje za javnost, 17. lipnja 2016. URL: http://www.mzoip.hr/hr/ministarstvo/ vijesti/odrzan-sastanak-medudrzavne-radne-grupe-za-pracenje-stanja-zraka-u-slavonskom-brodu-i-brodu.html (12.11.2018.)

Ministarstvo zaštite okoliša i energetike Republike Hrvatske (2018). Zaštićena područja: O zaštićenim područjima. URL: http://www.mzoip.hr/hr/priroda/zasticena-podrucja.html (12.11.2018.)

Molnar, M. (2014). Zašto je pukao nasip kod Rajeva sela? Hrvatski radio Vukovar, 3. srpnja 2014. URL: http://www.hrv.hr/vijesti/aktualnosti/item/5729-zasto-je-pukao-nasip- kod-rajeva-sela (29.04.2018.)

M. Ž. (2016). „Bila bi to katastrofa“ Plitvicama prijeti da dođu na listu ugrožene svjetske prirodne baštine. Dnevnik.hr, 20. srpnja 2016. URL: https://dnevnik.hr/vijesti/hrvatska /plitvicama-prijeti-da-dodju-na-listu-ugrozene-svjetske-prirodne-bastine--- 443958.html (12.11.2018.)

Nadilo, B. (2014). Osjećaj nemoći i straha: kakvoća zraka u Slavonskom Brodu. Gradevinar, 66(3): 269-275.

$\mathrm{Na}$ Savi se pojavila velika naftna mrlja, službe na terenu (2018). Index.hr, 10. listopada 2018. URL: https://www.index.hr/vijesti/clanak/na-savi-se-pojavila-velika-naftna-mrlja- sluzbe-na-terenu/2029404.aspx (23.12.2018.)

N. D. (2018). Crodux dobio suglasnost za gradnju plinovoda do RN Bosanski Brod. Energetika-net, 3. svibnja 2018. URL: http://www.energetika-net.com/vijesti/ plin /crodux-dobio-suglasnost-za-gradnju-plinovoda-do-rn-bosanski-brod-26833 (23.12.2018.)

Okvirni sporazum o slivu rijeke Save (Kranjska Gora, 2002), Narodne novine - Mecunarodni ugovori, 14/2003; Službeni glasnik BiH, 8/2003. 
Osnovan regionalni tim: $\mathrm{BiH}$, Hrvatska i Srbija zajedno u borbi protiv mina (2014). 24sata.info, 23. svibnja 2014. URL: http://24sata.info/vijesti/bosna-i-hercegovina/195105-osnovan-regionalni-tim-bih-hrvatska-i-srbija-zajedno-u-borbi-protiv-mina.html (12.11.2018.)

Patković, N. i Mužević, Ž. (2014). Video, foto: Drama na istoku Hrvatske U akciji je više od tisuću vojnika, rade danonoćno Slavonski Brod Nasip pomalo pušta, saniraju ga Narastao broj mrtvih Pronađen leš muškarca. Jutarnji list, 19. svibnja 2014. URL: https://www.jutarnji.hr/vijesti/hrvatska/video-foto-drama-na-istoku-hrvatske-u-akciji-je-vise-od-tisucu-vojnika-rade-danonocno-slavonski-brod-nasip-pomalo-pusta-saniraju-ga-narastao-broj-mrtvih-pronaden-les-muskarca/801910/ (12.11.2018.)

Pavelić, B. (2017). Ravnatelj NP Plitvička jezera Anđelko Novosel: „Apartmanizaciju na Plitvicama treba zaustaviti“. Novi list, 23. srpnja 2017. URL: http://www.novilist.hr /novilist_public/Vijesti/Hrvatska/Ravnatelj-NP-Plitvicka-jezera-Andelko-NovoselApartmanizaciju-na-Plitvicama-treba-zaustaviti?meta_refresh=true (12.11.2018.)

Prekogranični ekološki problem: Piju li Bišćani zagađenu vodu? (2014). Krupljani. $B A$, 29. listopada 2014. URL: https://www.krupljani.ba/usk/prekograniceni-ekoloski-problem- piju-li-biscani-zagadenu-vodu.html (12.11.2018.)

Pribičević, B., Medak, D. i Kordić, B. (2007). Primjena dvofrekventne batimetrije u određivanju sedrenih naslaga. Geodetski list, 61(84)(1): 1-18.

Prihvaćen zajednički projekt $\mathrm{BiH}$, Hrvatske i Srbije za zaprašivanje komaraca (2014). Klix.ba, 29. svibnja 2014. URL: https://www.klix.ba/vijesti/bih/prihvacen-zajednicki-projekt-bih-hrvatske-i-srbije-za-zaprasivanje-komaraca/140529103 (12.11.2018.)

Republički zavod za zaštitu kulturno-istorijskog i prirodnog nasljeđa Republike Srpske (2016). Zaštićena područja prirode u Bosni i Hercegovini. URL: http://www.nasljedje.org /prirodno-nasljedje/266 (12.11.2018.)

RIMETEO (2014). Svibanj 2014.: Mjesec katastrofalnih poplava na jugoistoku Europe. 2. lipnja 2014. URL: http://rijeka.meteoadriatic.net/svibanj-2014-mjesec-katastrofalnih- poplava-na-jugoistoku-europe/ (12.11.2018.)

Ružić, V. (2011). Marketing zaštićenog područja - studija slučaja: Nacionalni park Plitvička jezera. Zbornik radova Međimurskog veleučilišta u Čakovcu, 2(2): 77-83.

Ružić, V. i Šutić, B. (2014). Ecological Risks of Expansive Tourist Developement in Protected Areas - Case Study: Plitvice Lakes National Park. Collegium Antropologicum, 38(1): 241-248.

Slanjankić, A. (2016). Što izaziva poplave u jugoistočnoj Europi? Deutsche Welle, 27. travnja 2016. URL: http://www.dw.com/hr/\%C5\%A1to-izaziva-poplave-u- jugoisto\%C4\%8Dnoj-europi/a-19217295 (12.11.2018.)

Smajilhodžić, R. (2014). Balkans floods trigger Bosnia’s worst exodus since war - deathtoll rises to at least 47. Signs of the Times, 20. svibnja 2014. URL: https://www. sott.net/article/279401-Balkans-floods-trigger-Bosnias-worst-exodus-since-wardeathtoll- rises-to-at-least-47 (12.11.2018.)

Sporazum između Vlade Republike Hrvatske i Vijeća ministara Bosne i Hercegovine o suradnji u području zaštite okoliša i održivog razvoja, Službeni glasnik BiH-Međunarodni ugovori, 2/17; Narodne novine - Medunarodni ugovori, 4/2016. 
Stilinović, B. (1979). Bakteriološka istraživanja Bijele i Crne rijeke i nekih plitvičkih jezera. Acta Botanica Croatica, 38(1): 79-86.

Ministarstvo vanjske trgovine i ekonomskih odnosa Bosne i Hercegovine, Federalno ministarstvo okoliša i turizma i Program Ujedinjenih nacija za okoliš (2016). Strategija i akcioni plan za zaštitu biološke raznolikosti Bosne i Hercegovine (2015- 2020). URL: http://www.fmoit.gov.ba/download/NBSAP\%20BiH_20160315_bos.pdf (12.11.2018.)

Strategija održivog razvitka Republike Hrvatske, Narodne novine, 30/2009.

Strategija upravljanja vodama, Narodne novine, 91/2008.

S. V. (2013). Dodik: Rafinerija u Bosanskom Brodu ne zagađuje zrak. Dnevnik.hr, 17. travnja 2013. URL: https://dnevnik.hr/vijesti/svijet/dodik-rafinerija-u-bosanskom-brodu-ne- zagadzuje-zrak---282928.html (12.11.2018.)

S. Ve. (2017). Kraj najveće sramote hrvatskog bisera? Dnevnik.hr, 18. svibnja 2017. URL: https://dnevnik.hr/vijesti/hrvatska/potpisan-sporazum-kojim-ce-rijesiti-problem-odvodnje-na-podrucju-nacionalnog-parka-plitvicka-jezera---477006.html (12.11.2018.)

„Što prije građanima Sl. Broda moramo osigurati čisti zrak“ (2018). N1, 10. listopada 2018. URL: http://hr.n1 info.com/Vijesti/a338610/Sto-prije-gradjanima-Sl.-Broda-moramo- osigurati-cisti-zrak.html (23.12.2018.)

Terzić, A. (2013). BiH i zaštita okoliša: zakoni kojih nema. Osservatorio Balcani e Caucaso, 16. svibnja 2013. URL: https://www.balcanicaucaso.org/bhs/zone/Bosna-iHercegovina/BiH-i-zastita-okolisa-zakoni-kojih-nema-135838 (12.11.2018.)

Tišma, S., Kramarić, Ž., Ozimec, K. i Demonja, D. (2006). Analysis of Ecotourism Development Potential in Protected Areas in the Republic of Croatia and Recommendations. Croatian International Relations Review, 12(44/45): 105-117.

Tot-Đerđ, P. (2014). Apel za hitno rješavanje problema onečǐćcenja zraka - moguće podizanja tužbe protiv odgovornih institucija. SBPeriskop, 5. rujna 2014. URL: http:// www.sbperiskop.net/kolumne/ptderd/apel-za-hitno-rjesavanje-problema- oneciscenja-zraka-moguce-podizanja-tuzbe-protiv-odgovornih-institucija (12.11.2018.)

Tot-Đerđ, P. (2016). Potpisan Sporazum između RH i BiH - Brođani i dalje u iščekivanju. SBPeriskop, 30. travnja 2016. URL: http://www.sbperiskop.net/kolumne/ptderd/ potpisan-sporazum-izmedu-rh-i-bih-brodani-i-dalje-u-iscekavanju (12.11.2018.)

Ugovor između Vlade Republike Hrvatske i Vlade Bosne i Hercegovine o uređenju vodnogospodarskih odnosa, Narodne novine - Medunarodni ugovori, 12/96; Službeni glasnik BiH - Medunarodni ugovori, 6/96.

UNDP Bosna i Hercegovina (2017). EU Direktiva o poplavama uvrštena u Zakon o vodama Republike Srpske. 16. studenoga 2017. URL: http://www.ba.undp.org/content/bosnia_and_herzegovina/bs/home/presscenter/articles/2017/11/16/eu-direktiva-o-poplavama- uvr-tena-u-zakon-o-vodama-republike-srpske.html (23.12.2018.)

UNESCO (2016). Plitvice Lakes National Park (Croatia). Analysis and Conclusion by World Heritage Centre and the Advisory Bodies in 2016. URL: http://whc.unesco. org/en/soc/3487 (12.11.2018.) 
Upravni odjel za komunalno gospodarstvo i zaštitu okoliša Brodsko-posavske županije (2015). Izvješće o stanju kvalitete zraka na području Brodsko-posavske županije u 2014. godini. Slavonski Brod: Upravni odjel za komunalno gospodarstvo i zaštitu okoliša Brodsko-posavske županije.

Uredba o ekološkoj mreži, Narodne novine, 124/2013,105/2015.

Uredba o emisijskim kvotama za određene onečišćujuće tvari u zraku u Republici $\mathrm{Hr}$ vatskoj, Narodne novine, 108/2013 i 19/2017.

Uredba o objavi Sporazuma između Vlade Republike Hrvatske i Vijeća ministara Bosne i Hercegovine o suradnji u području zaštite okoliša i održivog razvoja, Narodne novine - Medunarodni ugovori, 4/2016.

Uredba o programu Natura 2000 - zaštićena područja u Evropi, Službene novine Federacije $\mathrm{BiH}, 41 / 11$.

Uredba o vrstama i sadržaju planova zaštite od štetnog djelovanja voda, Službene novine Federacije BiH, 26/09.

Variščić, A. (2012). Zaštita prirode Medunarodni standardi i stanje u Bosni i Hercegovini. Konjic: Udruženje za zaštitu okoline Zeleni Neretva.

Vlada Federacije Bosne i Hercegovine, Europska unija, Ujedinjeni narodi i Svjetska banka (2014). Procjena potreba za oporavkom i obnovom u Bosni i Hercegovini Poplave, 14.-19. maj. Sažetak. URL: http://fondzapomocnastradalimfbih.gov.ba/userfiles/file/ procjena-potreba-za-oporavkom-i-obnovom-sazetak-u-eur-3.pdf (12.11.2018.)

Vlada Federacije Bosne i Hercegovine (2018). Program rada Vlade Federacije BiH za 2018. godinu. Sarajevo. URL: http://parlamentfbih.gov.ba/dom_naroda/v2/userfiles/file/Materijali\%20u\%20proceduri_2018/Program\%20rada\%20Vlade\%20 FBiH\%20za\%202018_17_01\%20bos.pdf (29.04.2018.)

Vlada Republike Hrvatske (2017). Plinofikacijom Rafinerije nafte Brod do poboljšanja kvalitete zraka u Slavonskom Brodu. 31. listopada 2017. URL: https://vlada. gov.hr/vijesti/plinofikacijom-rafinerije-nafte-brod-do-poboljsanja-kvalitete-zraka-u-slavonskom-brodu/22745 (12.11.2018.)

Vlada Republike Hrvatske (2018). Vlada odgovara na pitanja predstavnika građana Slavonskog Broda. 18. travnja 2018. URL: https:/vlada.gov.hr/vijesti/vlada-odgovara-na-pitanja-predstavnika-gradjana-slavonskog-broda/23730 (12.11.2018.)

Vladin Izveštaj o poplavama (2014). Nedeljnik Vreme, 3. srpnja 2014. URL: http:// www.vreme.com/cms/view.php?id=1210756 (12.11.2018.)

Voda je izbrisala granice: U modi je biti čovjek! (2014) Klix.ba, 24. svibnja 2014. URL: https://www.klix.ba/vijesti/bih/voda-je-izbrisala-granice-u-modi-je-biti-covjek-/140524022 (12.11.2018.)

Vojić, F. (2017). Piju li građani Bihaća fekalije koje dolaze iz Hrvatske? Al Jazeera Balkans, 8. rujna 2017. URL: http://balkans.aljazeera.net/vijesti/piju-li-gradani-bihaca-fekalije-koje-dolaze-iz-hrvatske (12.11.2018.)

Vurnek, M., Brozinčević, A., Briški, F., Matoničkin Kepčija, R. (2016). Distributional patterns of fecal indicator bacteria in spring area of Plitvice Lakes National park. Periodicum Biologorum, 118(1):37-44. 
Zakon o vodama, Narodne novine, 153/09, 63/11, 130/11, 56/13, 14/14, 46/18.

Zakon o vodama, Službene novine Federacije BiH, 70/06.

Zakon o vodama, Službeni glasnik Republike Srpske, 50/06, 92/09.

Zakon o zaštiti okoliša, Narodne novine, 80/13, 153/13, 78/15, 12/18, 118/18.

Zakon o zaštiti okoliša, Službene novine Federacije BiH, 33/03, 38/09.

Zakon o zaštiti prirode, Narodne novine, 80/13, 15/18, 14/19.

Zakon o zaštiti prirode, Službene novine Federacije BiH, 66/13.

Zakon o zaštiti životne sredine, Službeni glasnik Republike Srpske, 71/2012, 79/2015.

Zavod za vodoprivredu d.d. Sarajevo i Zavod za vodoprivredu d.o.o. Mostar (2012). Strategija upravljanja vodama Federacije Bosne i Hercegovine 2010.-2022. URL: http://www.fzofbih.org.ba/userfiles/file/strategija_vode.pdf (12.11.2018.)

$\mathrm{Za}$ Srbiju i BiH 1,846 milijardi eura pomoći (2014). Al Jazeera Balkans, 16. lipnja 2014. URL: http://balkans.aljazeera.net/vijesti/za-srbiju-i-bih-1846-milijardi-eura -pomoci (12.11.2018.)

Zelena akcija (2009). Zdravlje i okoliš Hrvatska i EU. Publikacija u sklopu projekta Utjecaj hrvatskog pridruživanja EU na zdravlje i okoliš. Zagreb: Zelena akcija. 


\title{
CROSS-BORDER ENVIRONMENTAL POLLUTION BETWEEN THE REPUBLIC OF CROATIA AND BOSNIA AND HERZEGOVINA: THREE CASE STUDIES
}

\author{
Tanja Jurić
}

\begin{abstract}
The development of modern society is accompanied by a growing number and types of risks. This paper looks at cross-border environmental pollution as one such risk. Coping with pollution by limiting state's effort on its territory alone is insufficient as pollution arises and spreads everywhere and cannot be restricted by state borders. For this reason, cooperation between states is crucial, including the definition of standards and mechanisms for pollution prevention and reduction. This article analyses three case studies of cross-border environmental pollution between the Republic of Croatia and Bosnia and Herzegovina: air pollution in Croatian city of Slavonski Brod, caused by the emissions of harmful substances into the air from the Oil Refinery Brod in Bosnia and Herzegovina; the floods that hit the entire region in May 2014; and the creation of the so-called "seventeenth lake" in Plitvice Lakes National Park as the results of unsuitable wastewater system, which caused the pollution of drinking water source in the Bosnian-Herzegovinian city of Bihac. In all three cases the specific context of cross-border pollution is described, as well as key social actors involved in the problem and its resolution, and the ways in which the countries are coping with cross-border pollution. Additionally, European Union's environmental legislation and international environmental conventions, which are relevant for environmental legislations of both states, are also analysed. By analysing these three cases, we conclude that both states need to improve their environmental policies, with a particular emphasis on the importance of intergovernmental collaboration for achieving a more effective risk management of cross-border pollution.
\end{abstract}

Key words: Bosnia and Herzegovina, Croatia, floods, cross-border environmental pollution, Oil Refinery Brod, "seventeenth lake", Plitvice Lakes, risk management

\section{GRENZÜBERSCHREITENDE UMWELTVERSCHMUTZUNG ZWISCHEN DER REPUBLIK KROATIEN UND BOSNIEN UND HERZEGOWINA: DREI FALLSTUDIEN}

Tanja Jurić

\section{Zusammenfassung}

Parallell zur Entwicklung der modernen Gesellschaft wachsen die Zahl und die Arten von Risiken, denen die Gesellschaft begegnet. Eines davon ist die grenzüberschreitende Umweltverschmutzung. Die Bemühungen von Staaten, mit der Verschmutzung im eigenen Land fertig zu werden, genügt nicht, weil die Verschmutzung sich über die Staatsgrenzen hinausbreitet. Aus dem Grunde ist eine Zusammenarbeit zwischen Staaten notwendig, damit Standards und Mechanismen für deren Vorbeugung und Minderung festgesetzt werden können. Im Artikel werden drei Fallstudien der grenzüberschreitenden Umweltverschmutzung zwischen der Republik Kroatien und Bosnien und Herzegowina dargestellt: Die Luftverschmutzung in Slavonski Brod, durch Freilassung von Schadstoffen in die Luft aus der Erdölraffinerie Brod in BuH verursacht; Überschwemmungen, von denen die Region im Mai 2014 betroffen wurde; der sogenannte „siebzehnte See“ der Plitvizer Seen, der wegen eines mangelhaften Entwässerungssystems eine Verschmutzung der Trinkwasserquelle in Bihać in BuH verursacht hat. In allen drei Fällen sind der spezifische Kontext der grenzüberschreitenden Verschmutzung, die an der Problemlösung beteiligten Akteure, sowie die Art und Weise beschrieben, wie Staaten mit der grenzüberschreitenden Verschmutzung fertig werden. Außerdem werden die EU-Gesetzgebungsakte über Umweltschutz und die, für die Gesetzgebung der beiden Staaten relevanten 
Weltkonventionen, berücksichtigt. Durch die Analyse der drei Fälle sind wir zum Schluß gekommen, dass die beiden Staaten ihre Umweltpolitik verbessern sollen, dabei liegt die Betonung auf der Wichtigkeit einer zwischenstaatlichen Zusammenarbeit, damit eine effizientere Risikoverwaltung der grenzüberschreitenden Verschmutzung erzielt werden kann.

Schlüsselwörter: Bosnien und Herzegowina, Kroatien, Überschwemmungen, grenzüberschreitende Umweltverschmutzung, Erdölraffinerie Brod, der „siebzehnte See“ der Plitvizer Seen, Risikoverwaltung 